\title{
Empirical and Normative Economics: A Game Theoretic Approach
}

\author{
Frederick Betz \\ Institute for Policy Models, Enumclaw, WA, USA \\ Email: fbetz@venture2reality.com
}

How to cite this paper: Betz, F. (2020). Empirical and Normative Economics: A Game Theoretic Approach. Theoretical Economics Letters, 10, 655-695. https://doi.org/10.4236/tel.2020.103042

Received: March 2, 2020

Accepted: June 25, 2020

Published: June 28, 2020

Copyright $\odot 2020$ by author(s) and Scientific Research Publishing Inc. This work is licensed under the Creative Commons Attribution International License (CC BY 4.0)

http://creativecommons.org/licenses/by/4.0/

\section{(c) (i) Open Access}

\begin{abstract}
An important problem in public finance is the interaction of public finance with private finance-particularly when private financial markets crash, then bank runs occur, and a central bank needs to bail out the banks to prevent an economic depression. Historically, private financial markets have periodically crashed (financial bubbles); and then public finance (central bank reserves) have sometimes bailed out banks, to prevent a depression. The reason this pattern (of a lack of regulation to prevent financial bubbles, but then bailing out banks) has historically recurred has been the use of an idealized economic theory of "perfect market" - used in economic policy to avoid appropriate regulation of a financial market. In this research, we formulate a "game-theoretic approach" to include financial regulation as an explicit part of the model of a financial market. Future research direction from this game approach can extend the traditional "endogenous economic theory of markets" into an empirical modeling technique-which can ground economic theory in the real history of market instabilities.
\end{abstract}

\section{Keywords}

Public Finance, Political Economy, Government Regulation, Financial Bubbles, Market Imperfections

\section{Introduction}

We will extend the Keynes-Minsky theory of a financial market as institutionally based-through analyzing the strategies of agents (market players) in a "gametheoretic form". The advantage of a game-theory approach is to enable the explicit inclusion of government regulation as one institutional aspect of economic market theory. 
In a game-theory view, financial markets operate, not just simply under financial-agent logic but also under the rules of government regulation.

In gaming terms, the economic theory problem is how should government regulation operate in order to facilitate real markets operating efficiently (toward a perfection).

\section{Background: Market Imperfections}

First, we review the two schools of economics which have divided upon this issue of: whether the economic theory of a perfect market is empirically true or an ideal to which to aspire: Empirical or Normative Theory.

When is an economic theory empirically true? Economic history can provide the answer. For example: is the economic theory of the "perfect market" always empirically true? The historical answer is no. In the United States economic history, the empirically series of market failures and economic recessions/depressions (from 1857 to 2007) provide this negative answer (Kindelberger and Aliber, 2011).

- Panic of 1857-This was triggered by an excessive railroad investment, leading up to a stock market collapse, which triggered a bank panic and created an economic recession.

- Panic of 1873-Again, excessive investment created a stock bubble, whose collapse triggered a bank panic and subsequent economic recession.

- Panic of 1893-Again excessive investments in railroads, resulted in temporary overbuilding, triggering again a bank panic and recession-financial excess, market crash, bank panic, recession.

- Panic of 1896-Monetary policy about US currency began to be based both upon silver and gold, which, as monetary policy, created an economic depression when silver reserves declined.

- Panic of 1907-This was again a stock market failure, which began to trigger bank runs; but this was halted by JP Morgan Bank. Stopping the bank panics prevented a recession. Six years later, this event had encouraged the establishment of the U.S. central bank system (Federal Reserve System).

- Panic of 1929-A New York stock market bubble triggered three years of bank panics, resulting in the U.S. Great Depression, which lasted a decade.

- Panic of 2007-A U.S. real estate bubble was followed by the crash of a Wall Street financial derivatives market, and a global bank panic, creating a recession in the U.S.

Also, financial panics have been international. In Asia in 1997, there was an Asian fiscal crisis, triggered first by real estate and stock bubbles in Thailand, and then by a sharp decline in exchange-rate and out-flow of foreign capital. The market failure in 2007 required the U.S. government to bail out U.S. banks with $3 / 4^{\text {th }}$ of a trillion dollars. In Europe in 2011, there were bank panics in Euro countries, due to excessive sovereign debts, which triggered bank panics, and resulting depressions, particularly in Southern Europe, in Greece, Portugal, and Spain. 
A key issue in any social science discipline is this. Whether a proposed theory is empirically true or normatively true-true in fact or true in ideal? An empirically true theory is "Real" in an actual social situation; a normatively true theory is "Ideal" in an actual social situation. "Real" is what actually exists; and "Ideal" is what should exist, what is desired. Real theory is objectively true (existent); whereas Ideal theory is subjectively true (value).

Why is it important whether an economic theory is empirically real or ideally true? It is important because economic theory has often been used to guide and justify government policy decisions on economic policy. For example, as we have just seen from the list of the empirical instances of market failure (economic history), the economic theory of a perfect market can only be an Ideal theory - a state of the market to be desired. Yes, it is to be desired; but sometimes it is not actual.

Yet some government regulators have argued it was a Real theory (an empirical theory) - that financial markets are actually and always perfect. A historically recent example of this occurred in 2000 in U.S. economic history, when the Chair of the Federal Reserve System, Allen Greenspan, argued to the U.S. Congress that the relatively new financial market of "derivatives" should not be regulated because all markets were perfect. Yet only seven years later in 2007, that mortgage-derivatives market went bust; and it almost brought down the U.S. whole financial system (while also creating chaos in the world financial system). Why had Allen Greenspan argued that the economic theory was an empirically Real theory rather than an Ideal theory? Because he believed in the Exogenous school of economics, which we will next review.

\section{Background: Two Economic Schools about the Theory of Financial Markets}

It is important to avoid the kind of "Greenspan-Theory-Confusion" in formulating economic policy-the confusion which led to disastrous consequences in the world financial system in 2007-2008. This paper is a little long because we must first review how to "model" the Endogenous theoretical approach (KeynesMinsky) to a financial market, before we can extend the modeling analysis with a game-theoretic model.

This issue of Idealism or Realism about financial markets has been a central methodological issue in the history of economics in the United States (from 1937 to 2007) dividing economic theory in Exogenous and Endogenous Schools (This is a well-known story, but it is useful to see it again - to appreciate how "methodology" can divide academic schools in the social sciences, including economics).

The "Classical-Synthesis" economic school was called the "Exogenous school"-meaning the imperfections in a market were external to the functioning of the market. The opposing Neo-Keynesian economic school was called the Endogenous school-meaning that the imperfections in a market were internal to 
market operations. The Exogenous school argued that perfect market theory is Real, with any imperfections in a market as "external" to the market. In contrast, the Endogenous school argued that perfect market theory is Ideal, as empirically markets always contain imperfections "within" the market. (Greenspan belonged to the Exogenous school; but our focus here is on the Endogenous school).

In 2012 after the "Great Recession" in the U.S. due to the mortgage-derivatives market failure, some economists, such as Charles J. Whalen, saw these two foci about financial systems as converging: "In the mid-1970s, Wallace C. Peterson ... argued that institutionalism and the economics of John Maynard Keynes can be viewed as 'two trains on parallel tracks toward a common destination'. Today, in the wake of the Great Recession (2007) - the worst global economic downturn since the 1930s-those trains have finally reached the station. Their arrival is none too soon for economics and the world economy. The common destination of institutionalism and the economics of Keynes, the latter of which is currently called Post-Keynesian economics, is also called Post-Keynesian Institutionalism" (Whalen, 2012).

The Post-Keynesian Institutionalism school has emphasized that the institutional relation of Credit-to-Debt is an essential process (Endogenous) aspect of a financial market. This points to the essential role of banking in financial markets. Hyman Minsky wrote: “...the dynamics of contemporary capitalism ... characterizes all economic units by their financial portfolios. In all sectors, people and organizations constantly face the need to decide what assets to acquire and how to finance them. The result is a dynamic, paper world of financial liabilities, cash-flow commitments, and interrelated balance sheets-all dependent on expectations made against the backdrop of an uncertain future and an irreversible past" (Minsky, 1969). Minsky was asserting that the economic rationality of financial agents depends upon their institutional context and timing.

This emphasis (on the actual behavior of financial agents over time) had been a tradition in one approach to economics, called "institutional economics". In addition to Keynes and Minsky, institutional economics has had many seminal writers, such as: Thorstein Veblen, Walton Hale Hamilton, Adolf A. Berle. They all challenged a traditional economic "idea" that all economic agents behave purely "rationally", where the rationality is independent of place and time and institution, purely logical without context. In contrast, there was the economic assumption that all markets are perfect, if let alone-ruled by an invisible hand of the market.

But the institutional economists thought that the rationality of financial agents can depend upon the institutional context. For example, in the U.S. before the 1990s, most executive compensation in banking had been in the form of salaries and perks. But in the late 1980s, executive compensation moved increasingly to bonuses. The reason for this was three-fold. First, control of corporate boards passed from shareholders to corporate executives through proxy voting. Second, capital gains were at the time taxed at 
half the rate as dividends, so corporations could stop paying out dividends. (U.S. tax laws distorted financial incentives-resulting in unintended consequences). This gave executives large amounts of corporate "retained earnings" with which to buy other companies-thereby "purchasing" corporate growth and rising stock prices. Third, through such corporate acquisitions (and any other means executives could think of), executives sometimes focused exclusively upon the short-term future of the corporation in order to soon maximize the value of their stock bonuses. If in the long-term, a corporation failed because of excessive focus upon the short-term, then only shareholders and lower-ranking employees would lose savings and jobs. In such an eventuality, short-term bonuses would have already made the executives multi-millionaires.

In Wall Street banking, the transition of investment banks (from partnerships to corporations) facilitated banking executives to also focus upon bonuses. And such executive-bonus-policy encouraged executives of banks to ignore any long-term risks their employees were taking in making loans. Loan commissions increased revenue to fuel executive bonuses. This is why some banking executives allowed their hedge funds to engage in the bad banking practice of borrowing-short-and-lending-long. For example (as we shall soon review) in February 2008, hedge funds within the investment bank of Bear Sterns were unable to obtain renewed loans on their securitized mortgage bonds, and the funds failed. Bear Sterns, which had borrowed 6 billion dollars, also failed. Yet hedge fund managers and the CEO of Bear Sterns were already millionaires from previous years bonuses. As we shall soon see, this event triggered the Global Financial Crisis in 2007.

About exogenous economic theory, Charles J. Whalen had written: "Conventional economics is constructed around the notion of a barter economy. The starting point is that of a village fair: Money, finance, capital assets, and production can all be added, but ... Neo-Classical Synthesis (Exogenous school of markets) assumes that the central features of capitalism can be grasped without them. However, Neo-Keynesian Institutionalism (Endogenous school of markets) insists that institutions, not impersonal forces or universal laws of nature balance (the) wheel of the economy ... (For example) the Schumpeter-Minsky theory of capitalist development is institutionally based and finance-driven. It holds that capitalist development is shaped by the institutional structure, and that this structure is always evolving in response to profit-seeking activity" (Whalen, 2012).

For fiscal policy, it is important to use an empirically accurate model of financial markets. Using the right model for policy is important to the proper regulation of financial markets, which is critical in economic stability. Unstable financial markets result in "deflation"-always due to "overly-leveraged investments". For example, in 1933, Irving Fisher wrote: "(In deflation) ... two dominant factors (are) ... over-indebtedness to start with and deflation following soon af- 
ter ... the big bad actors are debt disturbances and price level” (Fisher, 1933).

Deflation is the economic process which lowers the values of all capital assets. It typically occurs after a financial bubble, after banks have lent too much money to leveraged speculators (who had acted upon their cognitive reflexivity). When a financial bubble bursts, banks are left with worthless collateral, the collateral upon which they had lent to money to speculators. As bank collateral, the capital assets have deflated. Banks go toward insolvency, and bank runs occur. Credit is frozen; and the economy plunges into a recession/depression.

In the world of global trade, an unstable international financial system was characteristic of twentieth century and continues into the twenty-first century. The mark of "instability" in a financial system is a financial bubble. The pattern of financial instability begins with a financial bubble, which triggers bank panics, which stops commerce and plunges an economy into recession. Yet in the discipline of economics, there has been disagreement as to whether in financial markets this pattern is "accidental" or "inherent".

\section{Case Study: In 1997, the Regulatory Reform That Never Was}

The importance of including "regulation of markets" within the economic theory of markets (and not external, outside the theory of markets) can be seen historically in the non-regulatory event occurring in 1997 (which paved the path to the financial crisis of 2007). Adherents to the Exogenous school have sometimes played an important role in guiding economic policy.

In 1997, Allen Greenspan (then Chair of the Federal Reserve System) and Robert Rubin (then Secretary of Treasury) argued to the U.S. Congress that the new "derivatives financial markets" did not require regulation-because all markets are "perfect" (operating under some kind of "invisible hand"). Thus in 1997, there had been an opportunity for the U.S. government to regulate derivative transactions in the shadow-banking sector, but it was not taken on the advice of key regulatory officials of the U.S. Federal Government.

But not all regulators had agreed with Greenspan and Rubin. At that time in 1997, the Commodity Futures Trading Commission was headed by Brooksley E. Born. This U.S. Federal agency regulated options and futures trading, and Ms. Born wanted to extend its authority to regulate derivatives trading. Paul Goodman wrote: "Ms. Born was concerned that unfettered, opaque trading could 'threaten our regulated markets or, indeed, our economy without any federal agency knowing about it', she said in Congressional testimony. She called for greater disclosure of trades and reserves to cushion against losses" (Goodman, 2008).

But the other Federal regulators (notably Allan Greenspan, Chair of the Federal Reserve System and Robert Rubin, Secretary of Treasury) did not wish to regulate derivatives. Goodman wrote: “Ms. Born's views incited fierce opposition from Mr. Greenspan and Robert E. Rubin ... Treasury lawyers concluded that 
merely discussing new rules threatened the derivatives market. Mr. Greenspan warned that too many rules would damage Wall Street, prompting traders to take their business overseas" (Goodman, 2008).

Later another member of the Commission, Michael Greenberger commented how Greenspan viewed Brooksley: "Greenspan told Brooksley that she essentially didn't know what she was doing and she'd cause a financial crisis. Brooksley was this woman who was not playing tennis with these guys and not having lunch with these guys. There was a little bit of the feeling that this woman was not of Wall Street" (Goodman, 2008).

Also, the Secretary of Treasury, Robert Rubin was strongly opposed to regulating derivatives. Goodman wrote: "In early 1998, Mr. Rubin's deputy, Lawrence $\mathrm{H}$. Summers, called Ms. Born and chastised her for taking steps he said would lead to a financial crisis, according to Mr. Greenberger. Mr. Summers said he could not recall the conversation but agreed with Mr. Greenspan and Mr. Rubin that Ms. Born's proposal was 'highly problematic'. On April 21, 1998, senior federal financial regulators convened in a wood-paneled conference room at the Treasury to discuss Ms. Born's proposal. Mr. Rubin and Mr. Greenspan implored her to reconsider, according to both Mr. Greenberger and Mr. Levitt” (Goodman, 2008).

Still Ms. Born believed derivatives needed to be regulated and decided to act. Other regulators appealed to Congress to prevent this. Goodman wrote: "Ms. Born pushed ahead. On June 5, 1998, Mr. Greenspan, Mr. Rubin and Mr. Levitt called on Congress to prevent Ms. Born from acting until more senior regulators developed their own recommendations. Mr. Levitt says he now regrets that decision. Mr. Greenspan and Mr. Rubin were 'joined at the hip on this', he said. 'They were certainly very fiercely opposed to this and persuaded me that this would cause chaos"' (Goodman, 2008).

Alan Greenspan, Chair of the Federal Reserve, and Robert Rubin, Treasury Secretary, continued to urge Congress to ban any regulatory action on derivatives. Goodman wrote: "In November 1999, senior regulators recommended that Congress permanently strip the C.F.T.C. of regulatory authority over derivatives. Mr. Greenspan, according to lawmakers, then used his prestige to make sure Congress followed through. 'Alan was held in very high regard', said Jim Leach, an Iowa Republican who led the House Banking and Financial Services Committee at the time. 'You've got an area of judgment in which members of Congress have nonexistent expertise"' (Goodman, 2008).

Still some members of Congress had questions. In a hearing in 2000, Mr. Harkin asked about who would act if something went wrong in the derivatives market. Goodman quoted: "If you have this exclusion (of derivatives) and something unforeseen happens, who does something about it?' he asked Mr. Greenspan in a hearing. But Mr. Greenspan argued that Wall Street could be trusted. He said, 'There is a very fundamental trade-off of what type of economy you wish to have. You can have huge amounts of regulation, and I will guarantee 
nothing will go wrong, but nothing will go right either"' (Goodman, 2008).

In all his testimonies to Congress, the Chair of the Federal Reserve System continued to express his confidence in the "invisible-hand-of-the-market". Goodman wrote: "Later that year, at a Congressional hearing on the merger boom, Greenspan argued that Wall Street had tamed risk. Representative Bernard Sanders, an independent from Vermont, asked him: 'Aren't you concerned with such a growing concentration of wealth that if one of these huge institutions fails that it will have a horrendous impact on the national and global economy?' Mr. Greenspan replied, 'No, I'm not. I believe that the general growth in large institutions have occurred in the context of an underlying structure of markets in which many of the larger risks are dramatically, I should say, fully hedged"' (Goodman, 2008).

Congress passed and the President Clinton signed a bill which took derivatives regulation out of the purview of C.F.T.C. oversight. Derivatives went unregulated. And next, we will also review how this unregulated mortgage derivatives market crashed. And, with it, the global financial system nearly collapsed. Goodman pointed out: "The Wall Street debacle that swallowed firms like Bear Stearns and Lehman Brothers and imperiled the insurance giant American International Group has been driven by the fact that they and their customers were linked to one another by derivatives" (Goodman, 2008).

What we have seen in this instance of economic policy-making about regulating the derivatives financial market that the economic theory promoted by $\mathrm{Ru}$ bin and Greenspan was regarded by them as "empirically correct", when it was not. Real empiricism in economic theory, apparently, did not influence them.

\section{The Endogenous School of Economics}

Endogenous theory distinguishes between a commodity and a financial market. Commodities are produced goods which are consumed, such as: food, clothing, automobiles, etc. In commodity markets, the traditional economic model is a price-equilibrium model (Figure 1). The theoretical principle expressed in this model is that in the supply and demand curves of the market, when supply equals demand a "price equilibrium" will be reached. This is an economically desirable principle, optimizing prices between the different desires of economic agents, suppliers and demanders.

While Commodity markets exchange "commodities", financial markets exchange "capital assets". The difference lies in economic value. Commodities have only one economic value: present-consumption. Capital assets have two economic values: present-rent and future-liquidity.

This difference in economic values makes a difference in how, institutionally, economic agents behave in the two markets. In commodity markets, economic behavior aims toward a condition of supply-meeting-demand, a "price equilibrium". In financial markets, economic behavior aims for higher financial leverages, progressing toward a financial bubble, a "price disequilibrium". 


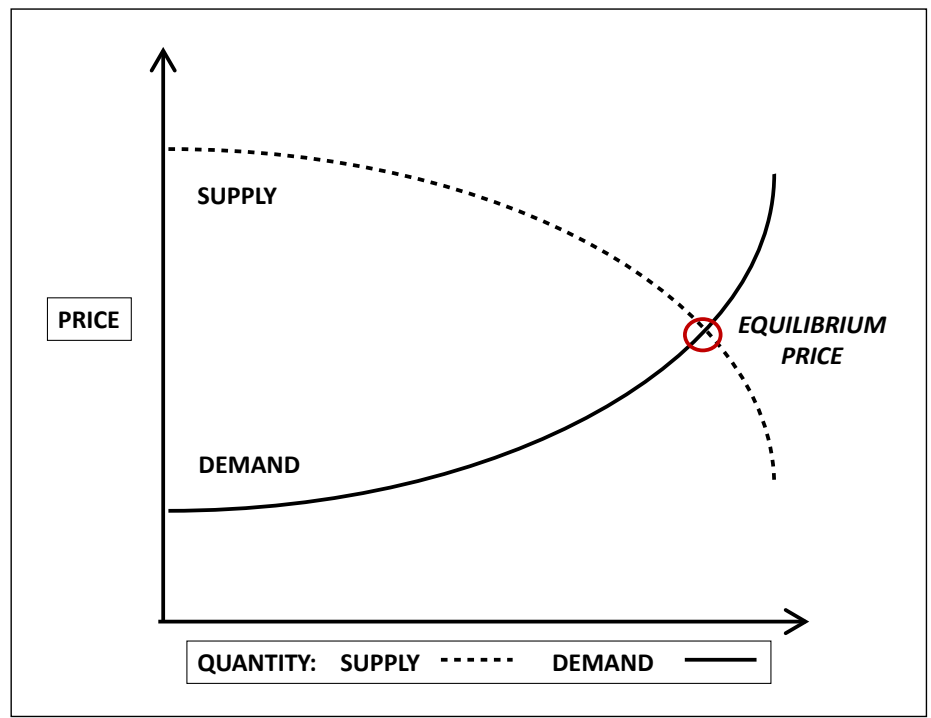

Figure 1. Economic equilibrium pricing of a commodity when supply equals demand.

Is an "equilibrium principle" empirically true always in both commodity and financial markets? The empirical answer is "no"! As we have listed, the harsh experiences with repeated financial crisis has pointed to the fact that while commodity markets may be empirically perfect at a time, financial markets seldom are perfect over time. Therefore, is whether the equilibrium-price market model is ever accurate for modeling financial markets? The answer again here is "no". We next review the Keynes-Minsky model of a financial market.

Early in economic theory, Irving Fisher (Fisher, 1933) and later John Maynard Keynes (Keynes, 1936) identified that instability occurs repeatedly in financial markets leading to a debt deflation. And later, this perception was explained by Hyman Minsky. Martin Wolf wrote about Minsky: "Hyman Minsky (19191996), fascinatingly, a post-Keynesian product of the Chicago School, developed one of the most comprehensive critiques of pre-crisis ... His crucial points were three: first, he believed that instability is an inherent feature of a dynamic capitalist economy, not just of the financial system; second, he doubted whether any regulatory rules could contain this instability durably; and, finally, he believed that the combination of 'Big Government' with the 'Big Bank' (the central bank) was the only way to contain the consequences of severe instability" (Wolf, 2012).

The Neo-Keynesians, such as Minsky, argued that the Neo-Classical economists were too narrowly focused on viewing an economy only as a production system (commodity markets). Ben Bernanke wrote: "Economists have not always fully appreciated the importance of a healthy financial system for economic growth or the role of financial conditions in short-term economic dynamics ..." (Bernake, 2007) Bernanke was pointing out the school of classical economists had assumed that "instability" of financial markets had little or no effect upon an economy. 
And on this, Hyman Minsky commented: "As Ben Bernanke points out the dominant microeconomic paradigm is an equilibrium construct ... that determines relative prices ... (The assumption is that) money and financial interrelations are not relevant to the determination of these equilibrium variables ... But if the basic microeconomic model is opened to include 'yesterdays, today, and tomorrows' ... (then finance can influence price equilibrium)" (Minsky, 1993). Minsky was pointing out that "time" (a temporal dimension) needs to be added into any microeconomic model of a financial market.

Drawing upon John Maynard Keynes' work, Minsky wrote: “In the General Theory, Keynes sought to create a model of the economy in which money is never neutral (to pricing). He did this by creating a model ... in which the price level of financial ... assets is determined in (financial) markets ... Each capital and financial asset yields an income stream, (which) has carrying costs and possessing some degree of liquidity ... The price level of assets is determined by the relative value of income and liquidity ...” (Minsky, 1982).

In Keynes' model of a financial system, a "time-dependence" is implicit in the concept of a "capital asset" having both a "present-income" and a "future-liquidity" (Keynes, 1936). A capital-asset is an investment which creates income and can later be sold. It produces an income stream (present-income) and also can be sold in the future (future-liquidity). The time dimension is from $\left(T_{1}\right)$ of a present-income to $\left(T_{2}\right)$ of future-liquidity. This present-to-future $\left(T_{1}\right.$ to $\left.T_{2}\right)$ temporal process occurs in a financial system as a transaction of "credit-debt". Minsky wrote: "Every capitalist economy is characterized by a system of borrowing and lending ... The fundamental borrowing and lending act ... is an exchange of 'money-now' for 'money-in-the-future'. This exchange takes place ... in a negotiation in which the borrower demonstrates to the satisfaction of the lender-that the money of the future part of the contract will be forthcoming... The money in the future is to cover both the interest and the repayment of the principle of the contract" (Minsky, 1975). A financial market makes the credit-debt contracts sellable over time, as a future-liquidity.

Thus in a financial system, three things are essential: 1) credit-debt transactions as a fundamental financial process, and 2) a capital-asset market for liquidity of the asset, and 3) money as a medium of value-exchange. Using Minsky's emphasis on a time dimension to model a financial market, the author diagramed such a temporal financial process, as in Figure 2 (Betz, 2014).

A financial capital-asset transaction occurs over time, beginning with a loan for an asset purchase, followed by rents (income stream) from the productivity of the capital asset, which are used for payments of the loan until the sale of the asset. Financial agents provide a purchase loan to the purchaser of the asset, receiving in turn from the purchaser loan payments on the debt over time from $\mathrm{T}_{1}$ through $\mathrm{T}_{3}$. Financial markets price the capital asset for purchase at time $\mathrm{T}_{1}$ and later for sale at time $\mathrm{T}_{4}$. 


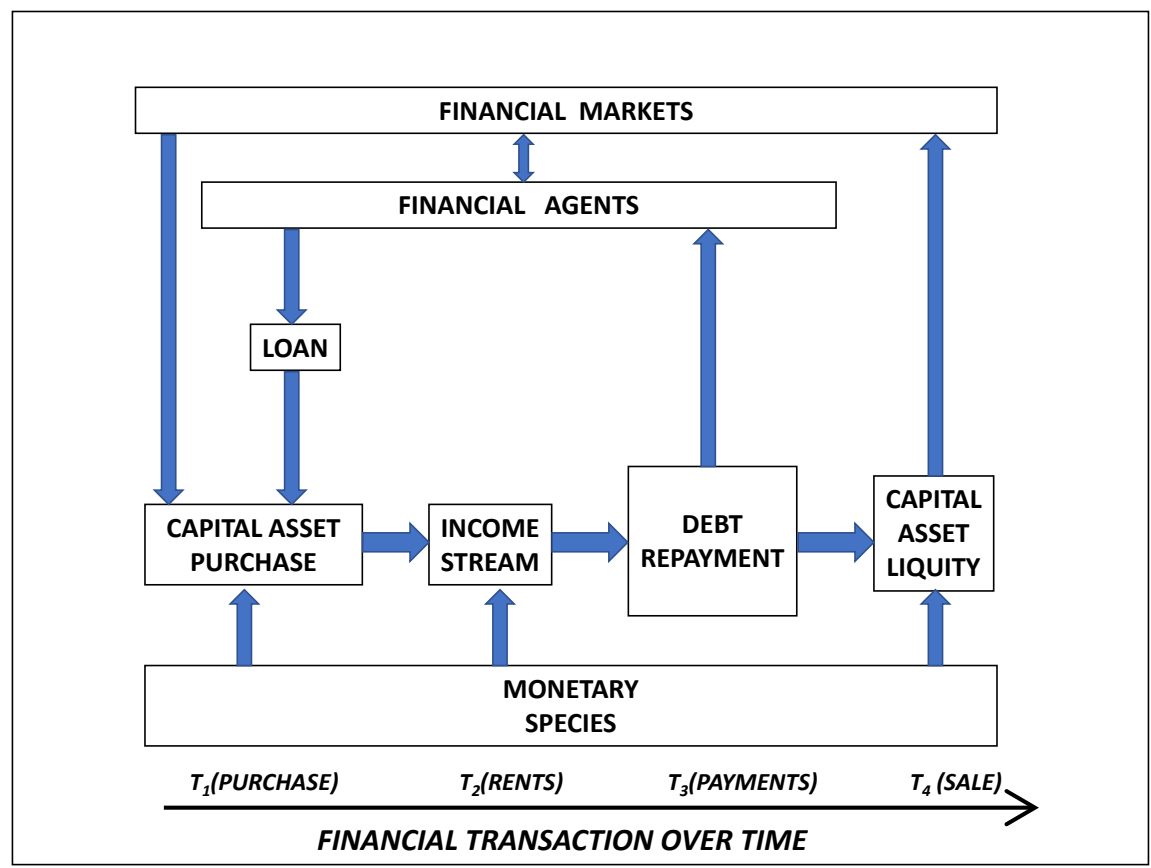

Figure 2. Transactions of capital assets in a keynes/minsky depiction of financial markets.

Debt makes a financial process operate. Yet one aspect of debt can destabilize the process; and this is "leverage". To increase profit, a financial system uses debt to finance the purchase of capital assets. Profits can be increased through financial leverage; and this is the financial rational of "leverage" (more "presentdebt" toward greater "future-wealth"). However, when present-debt is too large (too highly leveraged), it might not create future-wealth but, instead, bankruptcy. Excessive "leverage" increases the likelihood of bankruptcy and not future-wealth.

Earlier, this had been pointed out by Irving Fisher, who called a financial state of excessive-leverage as "debt deflation" (Fisher, 1933). Later Hyman Minsky called a state of "excessive financial leverage" as "Ponzi finance" (Minsky, 1982).

"Leverage" is the borrowing of a large percentage of the purchase price of a capital asset. Leverage increases profit when a capital asset is sold, but also increases risk of loss if the asset is not sold.

And even later, Paul McCulley also emphasized the importance of the economic role of "leverage" in finance. McCulley wrote: "At its core, capitalism is all about risk taking. One form of risk taking is leverage. Indeed, without leverage, capitalism could not prosper... And it is grand, while the ever-larger application of leverage puts upward pressure on asset prices. There is nothing like a bull market to make geniuses out of levered dunces ... (Speculation) begets ever riskier debt arrangements, until they have produced a bubble in asset prices. Then the bubble bursts ..." (McCulley, 2009).

Thus leveraged "present-debt" can increase "future-wealth"; but "excessive 
leverage" can lead to "bankruptcy". As shown in Figure 3, one can graph this impact of leverage on a price equilibrium model-by modifying the 2-dimentional "price-equilibrium chart" - with the addition of a $3^{\text {rd }}$-dimension of time (Betz, 2014). This graph shows a supply-demand curve at two different times, $\mathrm{T}_{1}$ and later $\mathrm{T}_{2}$. In the time-dimension, one can see how a "price-disequilibrium" situation can arise over time, as a "financial bubble".

It is "excessive leverage" in the financing of a financial market which allows a financial bubble to occur. If no speculation occurs in an asset market (financial market) then the equilibrium prices at $T_{1}$ and $T_{2}$ could be the same. But when speculation in the future-price at time $\mathrm{T}_{2}$ occurs in a financial market, a price bubble can begin. Fueled by "leveraged speculation" in the future price of an asset, a "disequilibrium pricing" of the asset grows-increases and increases until the financial bubble bursts.

Then the banks which funded the "leveraged speculation" hold assets greatly decreased in value (from the bursting of the bubble); and this places these banks at risk of "insolvency". When depositors perceive a bank has put itself at risk, through funding too much speculation, depositors run to take their money out of the bank-a bank panic. Bank panics close down risky banks, and freeze available credit. When too much credit is frozen in an economy, businesses have no access to operating funds and are forced to lay off workers or close doors.

Financial bubbles usually create to bank panics, unless a central bank intervenes to save the banks. And financial bubbles can be seen in stock markets. Figure 4 shows the NASDAQ stock market index in the United States for the time period from 1970 to 2010 .

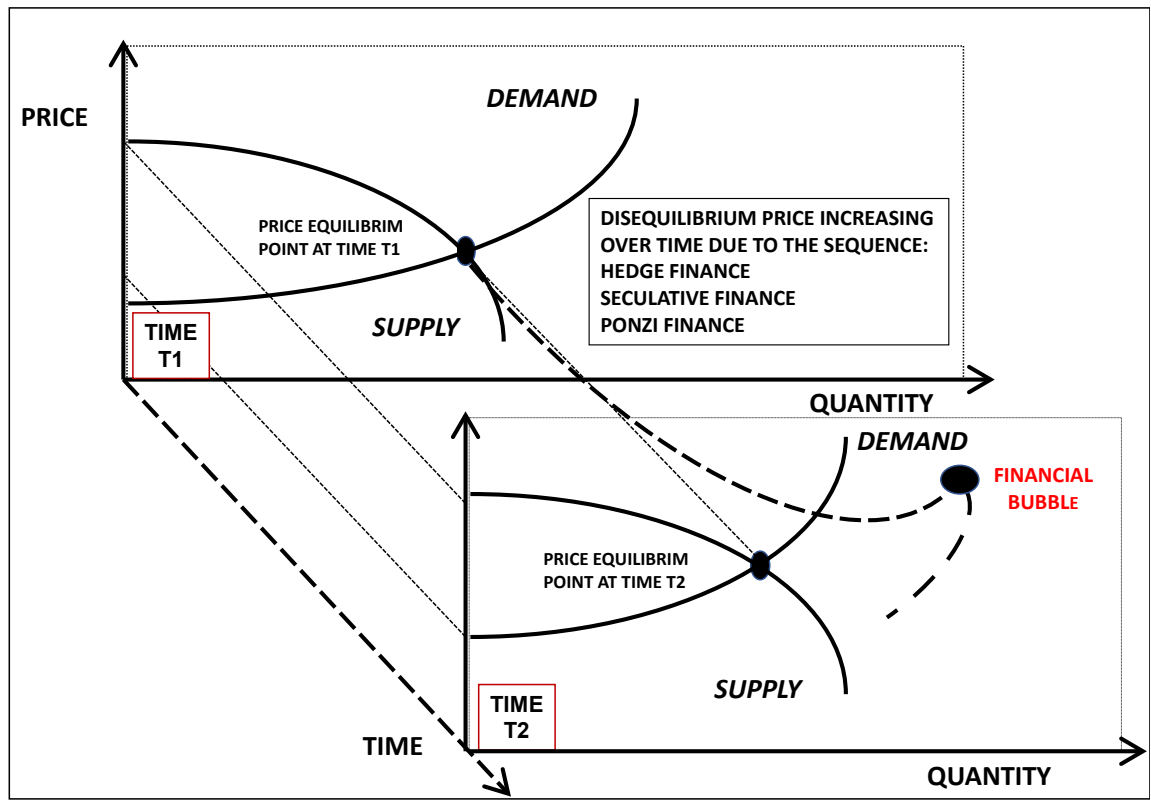

Figure 3. Three-Dimensional model of price disequilibrium of a financial market. 


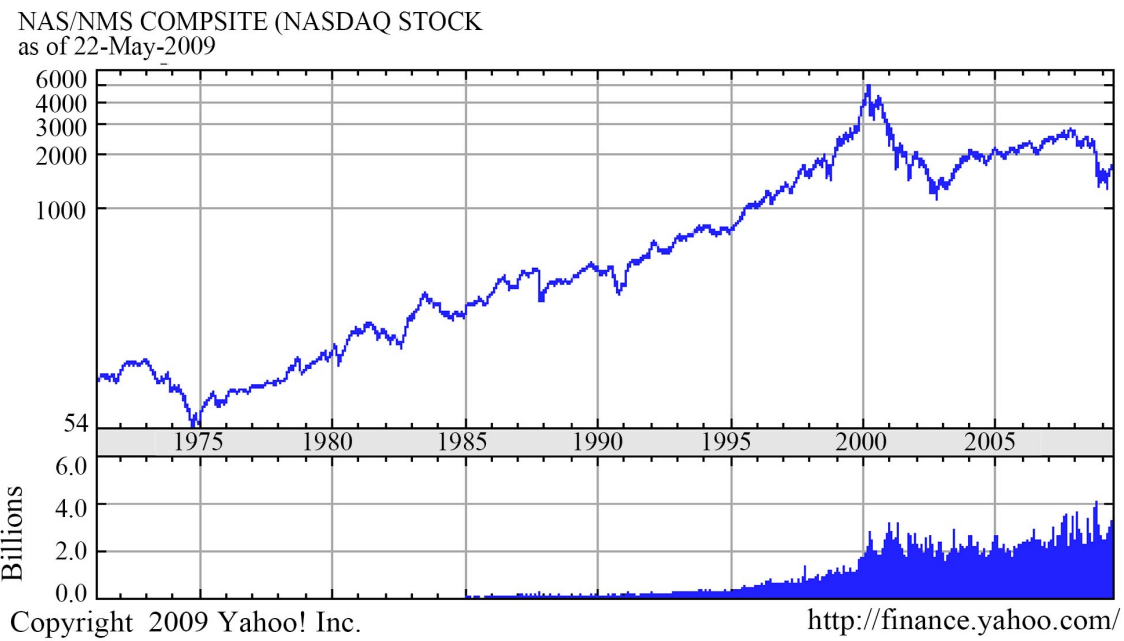

Figure 4. U.S. NASDAQ stock market index 1970-2010.

Here one can see the "dot.com" stock bubble from 1995 to 2000. Investor enthusiasm for businesses in the new Internet financed the start-up of hundreds of dot-com new ventures from 1998 to 2000. And the price index of the NASDAQ market rose from the stock index of "2000" in the year 1998 to "6000" in the year 2000-a three-fold growth in two years, a stock market bubble. The financial bubble burst in the year 2000, declining back to the index level of "2000"-a three-fold drop-wiping out the earlier stock market increase. Billions of dollars were lost by venture capitalist funds in this sudden collapse, due to their investments in new Internet companies-hence called the "dot.com" stock bubble.

Joseph Nocera and Tim Carvell summarized that time: "The Internet decade has seen the unscrupulous rewarded, the dimwitted suckered, the ill-qualified enriched at a pace greater than at any other time in history. The Internet has been a gift to charlatans, hypemeisters, and merchants of vapor ... And despite all that, it still changes everything" (Nocera and Carvell, 2000).

Upon a price-disequilibrium curve, one can fit a chart of a stock-market index over time onto the "Price-Time" plane of the three-dimensional price-disequilibrium graph, as in Figure 5.

This shows that a boom in a stock-market index chart is actually a "pricedisequilibrium graph" of the stock-price-index over time. The advantage of looking at it this way is to allow one to apply Minsky's categories of financial status to the stock-market graphs. When the average "price-to-earnings" (P/E) of a stock market is in the $10-15$ range, then the financial state of the stock market is in a "Conservative-financial" range. When the average "price-toearnings" (P/E) of a stock market is in the $16-25$ range, then the financial state of the stock market is in a "Speculative-financial" range. When the average "price-to-earnings" (P/E) of a stock market is above 25, then the financial state 
of the stock market is in a "Ponzi-financial" state. And Minsky emphasized that when any financial market is in a "Ponzi-financial" state, a financial bubble exists, just ready for bursting.

Because of the phenomena of financial bubbles, economic instability was seen by Neo-Keynesians as inherent to economic financial models. For this reason, the Neo-Keynesian School was called the "Endogenous" school of economics, meaning that instability is indigenous (inside) to an economy-through the disequilibrium pricing of asset markets in a financial bubble. The Neo-Classical Synthesis School was called an "Exogenous" school of economics because they believed instability was external to the economic system, of perfect markets.

As a precursor-when financial markets track away from an equilibrium pricing point (demand increasing dramatically over time with excessive leverage and without supply increasing) - then a financial bubble can be anticipated.

Regulatory intervention should occur before the critical time of Ponzi financing, as this time indicates a forthcoming devaluation-a bursting of the bubble.

This is the heart of the disagreement between the Exogenous and Endogenous Schools. Commodity markets can be "perfect" with prices occurring at an equilibrium point of supply-meeting-demand; but in contrast, financial markets are frequently "imperfect" with bubble pricing of capital assets, prices going off into the disequilibrium of a financial-bubble. The Endogenous school thinks that economic theory which is appropriate to the reality of financial markets is $\mathrm{Hy}$ man Minsky's “disequilibrium theory".

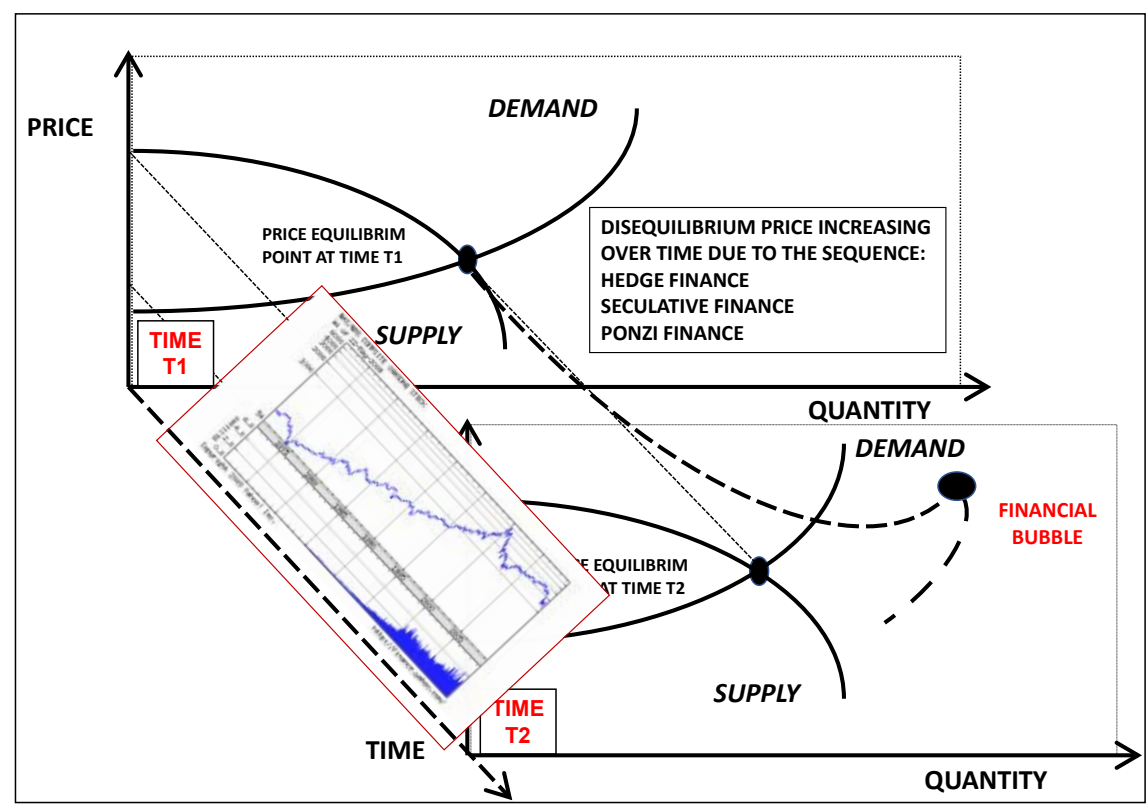

Figure 5. Stock market index as a chart on the price-time plane of a price-disequilibrium model. 


\section{Case Study: The 2007-2008 Global Financial Crisis}

To see an empirical case, wherein this disequilibrium model really captures historical economic reality, we will next briefly review the 2007-2008 Global Financial Crisis. (It will provide a historical case for seeing how a financial crisis can be analyzed in a new approach of game-theoretic models). This case was first published by Betz \& Khalil (Betz and Khalil, 2011).

\subsection{July 2007}

An article in The New York Times then summarized the crisis: "The first shoe (of the global financial implosion) to drop was the collapse in July 2007 of two hedge funds, owned by Bear Stearns, that had invested heavily in the subprime mortgage market" (New York Times, 2008). Banks, such as Bear Stearns had been making up bonds to be sold as a Collateralized Debt Object (CDO). These CDOs contained some good, low-risk "prime" mortgages but often also as much as $60 \%$ bad and risky "sub-prime" mortgages. The bank's funds had deliberately mixed prime with sub-prime mortgages in their bonds to increase the size and number of bonds. This resulted in the CDOs being contaminated with high risk. The buyers of the bonds did not know this, instead they had been told the CDO derivatives were low risk, based upon AAA bonds. The fund managers said that the mixture of sub-primes "spread the risk", but this was misleading as they really only increased risk-so much so that Bear Sterns would collapse when the CDO market collapsed.

\subsection{March 2008}

It would take eight months, from July 2007 to March 2008, for the "financial dominoes" to begin falling: "Bear Sterns kept reporting larger and larger losses on mortgage bonds. Bear Sterns was on the verge of bankruptcy, because it did not have sufficient reserve funds to satisfy Federal regulations to continue being chartered as a bank. Then in March 2008, the Fed staved off a Bear Stearns bankruptcy by assuming $\$ 30$ billion of Bear Sterns' liabilities and arranging its sale to JPMorgan Chase. The price of that sale was at 10 dollars a share, when only months earlier shares had been in the 100 dollars range; so that Chase acquired Bear Stearns 'for a price that was less than the worth of Bear's Manhattan skyscraper"' (New York Times, 2008). This was only the first bank that would fail to meet its banking-reserve requirements. Several more were to follow in the U.S and around the world.

\subsection{August 2008}

Next the two giant semi-public mortgage companies in the U.S., Fannie Mae and Freddie Mac, failed. "In August, government officials began to become concerned as the stock prices of Fannie Mae and Freddie Mac, government-sponsored entities that were linchpins of the housing market, slid sharply" (New York Times, 2008). Earlier the Federal government had guaranteed their bonds, but 
then the government nationalized both companies: "On Sept. 7, the Treasury Department announced it was taking over (nationalizing) Fannie Mae and Freddie Mac" (New York Times, 2008).

\subsection{September 2008}

In the same month, a second major investment bank fell: "On Sept. 12, top government and finance officials gathered for talks to fend off bankruptcy for Lehman Brothers. The talks broke down, and the government refused to step in and salvage Lehman as it had for Bear Sterns. Lehman's failure sent shock waves through the global banking system ..." (New York Times, 2008). Lehman Brothers could not meet bank-reserve requirements, having borrowed too much to buy mortgages, which they assembled into Collateralized Debt Objects-a $\mathrm{CDO}$ was a financial derivative, consisting only of interest payment without any collateral. Then that mortgage bond (which Lehman Brothers had borrowed to buy) behind a CDO was not saleable, as then the bond no longer paid interest. Also at the same time, a stock brokerage firm, Merrill Lynch, had also been buying large numbers of sub-prime mortgages to make up mortgage bonds for CDOs; and Merrill Lynch was forced to sell itself to the Bank of America.

Then an insurance company which had been selling insurance of CDOs to investment banks was on the verge of failure. "On Sept. 16, American International Group (AIG), an insurance giant on the verge of failure because of its exposure to exotic securities known as credit default swaps (CDS as insurance on a CDO derivative), was bailed out by the Fed in an $\$ 85$ billion deal" (New York Times, 2008). AIG had been issuing "insurance" on all those CDOs; all of which AIG couldn't pay if the CDOs failed.

Then with the shock of the bankruptcies, all the stock exchanges in the world imploded. "Stocks plunged, with the Standard \& Poor's 500-stock index losing nearly 9 percent, its worst day since Oct. 19, 1987" (New York Times, 2008). (As we will soon analyze, we will see that the mortgage-based CDO's were not real financial assets, as defined by Keynes-Minsky, but only fraudulent products-and not prevented by any regulation of the derivatives market. The CDO's would next be called "toxic assets").

\subsection{October 2008}

Finally, instead of earlier preventing the financial bubble, government regulators stepped in, to save the banks. "The U.S. Treasury Secretary, Henry M. Paulson Jr., publicly announced a three-page, $\$ 700$ billion proposal that would allow the government to buy toxic assets from the nation's biggest banks, a move aimed at shoring up their balance-sheets and restoring confidence within the financial system ... Many Americans were angered by the idea of a proposal that provided billions of dollars in taxpayer money to Wall Street banks, which many believed had caused the crisis in the first place". U.S. government intervention to save the U.S. banking industry was underway... (New York Times, 2008). 
The banking crisis spread around the world: "Banks in England and Europe had invested heavily in mortgage-backed securities offered by Wall Street... Over the weekend that followed the (U.S.) bailout's passage, the German government moved to guarantee all private savings accounts in the country, and bailouts were arranged for a large German lender and a major European financial company" (New York Times, 2008). But stock markets around the world continued to plunge. The central banks of many nations cut their prime interest rates to lower lending costs. Still the credit crises hadn't ended. The governments' investments in their banks increased: “... after a week in which stocks declined almost 20 percent on Wall Street, European and American officials announced coordinated actions that included taking equity stakes in major banks, including \$250 billion in investments in the United States” (New York Times, 2008).

The impact of the credit crisis spread from banks to stock markets to exchange rates and even the price of oil: "The volatility in the stock markets was matched by upheaval in currency trading as investors sought shelter in the yen and the dollar, driving down the currencies of developing countries and even the euro and the British pound. Oil-producing countries were hit by a sudden reversal of fortune, as the record oil prices reached over the summer were cut in half by October because of the world economic outlook" (New York Times, 2008). A global recession was anticipated: "But as the prospect of a severe global had begun, then Ben S. Bernanke, the Federal Reserve chairman, said 'there would be no quick economic turnaround even with the government's intervention', and the Dow plunged 733 points" (New York Times, 2008).

\subsection{November 2009}

Innovations in IT had made the whole global derivatives market scheme technically possible; and innovations in financial technology (securitization and hedge funds) made the Ponzi scheme of the whole mortgage-asset based derivatives possible. But, why had not the banks then used IT to unwind the market-revalue the derivatives? Instead, the US Secretary of Treasury obscured the issue-calling all the mortgage securitization of CDOs "toxic". He asked the US Federal government to allocate $\$ 700$ billion to make AIG and the US banks solvent. The political argument for the bailout whole was that big banks were too big to allow them to fail-even if they had been financially irresponsible.

Upon what economic theory was this argument positioned? No economic theory was argued-just that the banks were too "big" to fail. But if so, what government regulation would be necessary so that banks did not get too big to imperil a whole financial system? At the time, this policy question did not receive regulatory attention in the U.S.

In November 2008, the United States government elections were held; and a new President, Barack Obama, was elected: "The credit crisis emerged as the dominant issue of the presidential campaign in the last two months before the (U.S. presidential) election. The weakening stock market and growing credit cri- 
sis appeared to benefit Mr. Obama, who tied Mr. McCain to what he called the failed economic policies of President Bush and a Republican culture of deregulation of the financial markets. Polls showed that Mr. Obama's election on Nov. 4 was partly the fruit of the economic crisis and the belief among many voters that he was more capable of handling the economy than Mr. McCain" (New York Times, 2008).

\section{Institutional Flow-Model of a Financial-Assets Market}

Let us next review how a financial market is constructed, in an Endogenous model of "Wall Street" investment banking. As shown in Figure 6, a financial market consists of 1) specific kinds of financial products of capital assets that are sold and traded and 2) a Keynes-Minsky disequilibrium Price-Quantity-Time chart that depicts the financial market in which the financial products are traded (Betz, 2015).

This is an institutional model of the flow of capital into and from a financial market (as buyers or sellers of a financial asset). It uses "Systems notation", in which the "cloud" symbols are "sources" as origins of things entering the "flow" of the system-things which flow along the "arrow" lines of the system. The "rectangle" symbols are stocks of things which receive, send, or hold the things flowing along the arrows. The "circle-with-triangle" symbols are "control valves" which control the "rate-of-flow" of things along the arrows of the system. The "system" model of an institutional process indicates a flow of things between sources and stocks in the system, controlled by valves along the flow lines.

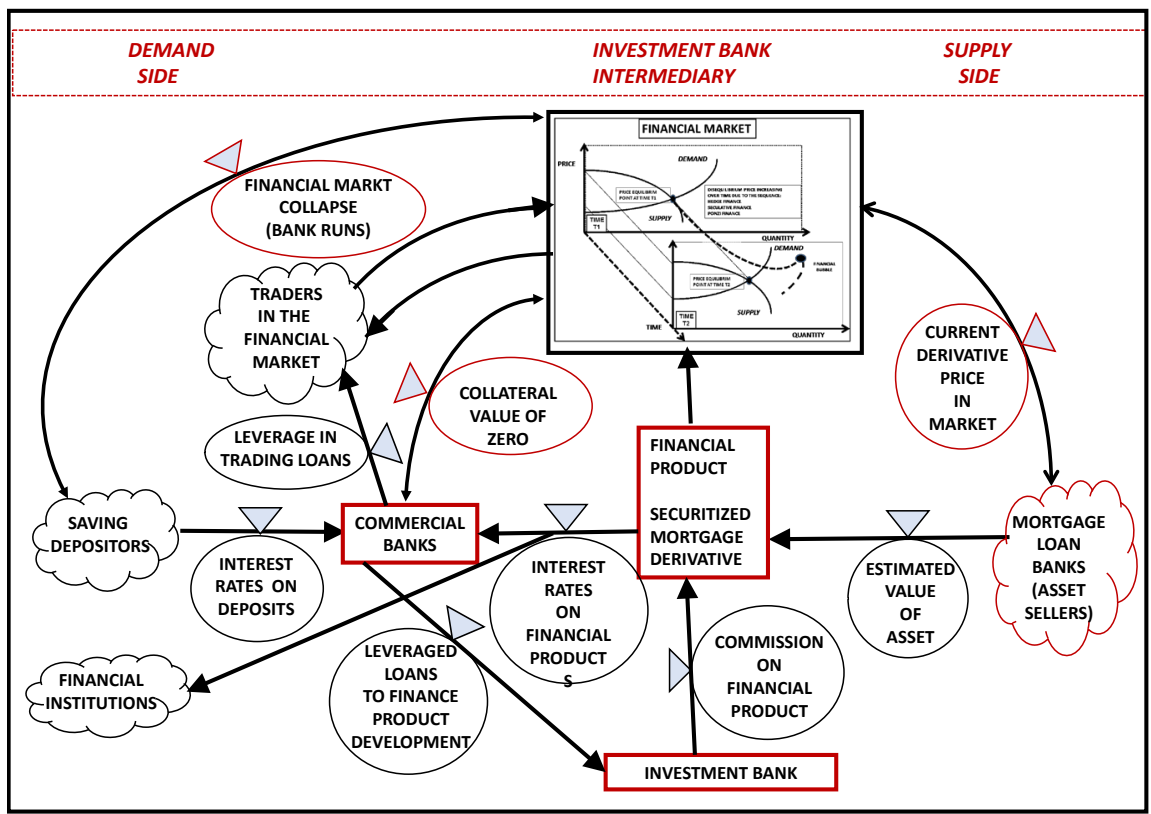

Figure 6. Institutional-process model of financial products traded in a financial market. 
In a systems model of investment bank procedures, there are two sources: a source of savings (buyers) and a source of assets (sellers). The flow is "capital" from a source of savers to a source of asset sellers, through the intermediary of the creation and trading of financial products: products created by investment banks and traded (in which over time might go into a financial bubble due to trader speculation in the market. A Minsky moment occurs when a financial bubble in the market collapses.

As a financial intermediary, an investment bank brings together a financial supply side of capital assets to trade in a market with a financial demand side of buyers of the assets. For example, when an investment backs assists a private company in making a public offering of stock, the private company sells equity assets as stock and purchasers of the stock buy equity in the company. The source in the supply side for the financial products are sellers of capital assets. The value of the financial product is controlled by a rate of the estimated-value-of-the-asset compared to the current-asset-price trading in the financial market. In financing the creation of a financial product, investment banks often get loans from commercial banks; and there is leverage in the product-development loans.

For example, in that 2007 case of securitized mortgage bonds, an investment bank's hedge fund within Bear Sterns borrowed $100 \%$ of the cost of the mortgage they purchased for securitization for one year from the commercial Bank of America(even when some of the mortgages in a bond wouldn't pay back principle for thirty years). That "leverage loan" required the commercial bank to annually renew the loan for up to 30 years. But after only a couple of years, the commercial bank stopped the annual renewal of the bank loan to Bear Sterns for its hedge fund. Then the hedge fund collapsed, and Bear Sterns went bankrupt, unable to pay the 6 billion dollars which the Bear Sterns hedge fund agent had borrowed. (Why had the federal regulators allowed commercial banks to make such leveraged loans on "toxic assets", like the securitized mortgages? Because seven years earlier, Federal regulatory officials had persuaded Congress not to regulate the new derivatives markets - arguing that all markets are perfect).

To model the demand side of financial products, the source of savings are individuals who make deposits in commercial banks, and the commercial banks purchase financial products. Also other financial agents (e.g. in mutual funds, hedge funds, pension funds, insurance companies) purchase financial products. The interest rate on the financial product is the controlling rate for its purchase by commercial banks and financial institutions. Commercial banks also make leveraged loans to traders in the financial market; and the trader's purchase of financial products is then held as collateral by the banks. Commercial banks use interest from a financial product to pay interest to their savings depositors.

The stability of the commercial banks can then depend 1) upon the quantity 
of financial product purchased by the bank and 2) upon the value of the collateral held on loans to traders. If the financial market collapses, then commercial banks are saddled with valueless financial products and the bad loans of the traders. The banks can become insolvent.

In the derivatives market crash of 2007, some large U.S. banks, holding mortgage bonds as collateral, collapsed. Others would have collapsed, without the U.S. government bail-out. (Earlier in 1929, the New York stock market bubble collapsed, and stocks held as collateral in banks which made loans to traders purchasing stocks-on-margin became valueless; and many of these banks went bust, through 1930, 1931, 1932-triggering the "Great Depression”).

Thus the disequilibrium model of a financial market is composed of the financial products which trade as capital assets. The financial market may move toward a price disequilibrium, if and when the market becomes hot, as traders bid the price of the financial product higher into a financial bubble. As traders bid higher prices in the market, they need to increase larger leverage in the loans for purchase. When the leverage in the loans gets too high, then the market grows into a financial bubble and can collapse. In a financial market collapse, the financial products which the commercial banks have held as collateral can become valueless (toxic assets). The banks can become insolvent and collapse (bank runs). But even with the FDIC, there are still bank runs, but U.S. depositors in banks are protected.

In the U.S. financial system, this institutional model of investment bank activities in making and enabling trades in a financial market has often been called "Wall Street". Suzanne Mcgee wrote: “All of the players (on Wall Street) perform functions that link the 'buy side', those who have capital and want to invest it profitably, and the 'sell side', those entities in need of capital. 'At its heart, when it is doing what it does best, Wall Street is a superb gatekeeper, making matches between investors and businesses, governments, or anyone else who needs to finance something', explains Mike Heffernan, a former Morgan Stanley banker" (Mcgee, 2010).

The sellers and buyers of financial products have different interests, which the investment bank must bridge in creating a financial product. Suzanne Mcgee wrote: "The sell side wants to get as much capital on the most favorable terms possible from the buy side-investors who range in size and importance from individuals to mutual fund conglomerates such as Fidelity, and include hedge funds, private equity funds, foundations, college endowments, pension funds, venture capital partnerships, and ultra-wealthy individual investors such as Microsoft co-founder Paul Allen or financier George Soros. In a perfect world, the sell side would love free money-with no interest payable, no specific term for repayment, and no promises about 
increasing the value of the investment. It is the myriad institutions that collectively make up Wall Street that (in exchange for a fee) bring together the two parties and negotiate a compromise: the terms on which the buy side is willing to invest some of its capital and the sell side is willing to agree to in order to get its hands on that capital. Banks have been fulfilling that kind of function in more limited ways for centuries ... created in the process of connecting the supply side (sellers) to the demand side (buyers), with investment banks acting as financial intermediaries. Wall Street exists to help investors and those in need of capital find their way through the financing maze. Investment bankers still not only link the two sides but also help them sort out what terms are fair for the kind of capital being sought" (Mcgee, 2010).

As shown in Figure 7, a model depicts that "abstraction of Wall Street" as "price-disequilibrium systems model" of a financial market; and we have applied this model to analyze the 2007-2008 mortgage-derivative market collapse. Therein, the red dotted-arrows highlight the relevant relationships in the institutional process of U.S. investment banks formulation of the securitized CDO financial products.

1) The estimated value of the mortgage bonds underlying the securitized interest-payments in a CDO fell to zero, as the mortgage bonds no longer earned interest during the life of the bond (since interest payments were sold to the CDO-the so-called "securitization" financial innovation).

2) This meant that the value fell to zero on the collateral held by commercial banks

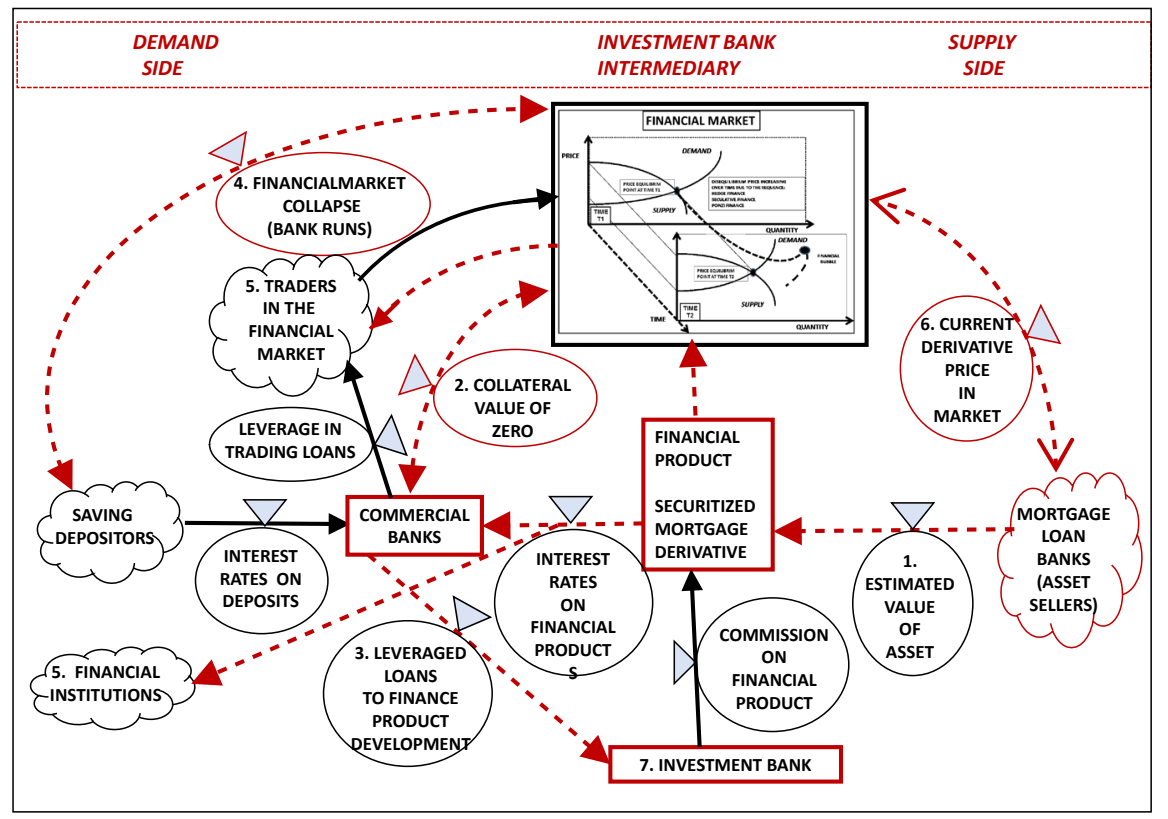

Figure 7. Financial products process for creating a financial market-in the Empirical Case of Mortgage-Securitized CDOs. 
3) On the leveraged loans which commercial banks had lent to Investment Banks to buy the mortgages.

4) When the housing market collapsed due to subprime mortgages, the CDO mortgage-securitized financial product market also collapsed-making the CDOs and the securitized mortgage bonds worthless (toxic assets).

5) Traders in the CDO market and financial institutions which bought the CDOs for investors lost money in the now worthless CDOs.

6) Current Derivative Price on the securitized CDOs went to zero (a toxic asset).

7) Investment Banks heavily into the securitized-mortgage CDO products went bankrupt (such as Bear Sterns, Lehman Brothers, and Merrill Lynch).

\section{Background: Idealism and Realism in Economic Theory}

We can see in the empiricism of economic history that government regulation to prevent a market financial bubble would be in the public good-benefiting the public by encouraging stability in a financial system. Why had the Exogenous School argued so long and hard against proper regulation of financial markets? To explore this, let us briefly review the methodological issue of public and privative good-of Idealism and Realism in economic theory. (This will establish the methodological need for including regulatory practice in economic models-the need for a game-theoretic approach to economic theory).

Economic theory has long used the phrase "public good" to indicate a product/service produced in a society which is shared by all members of society. This is in contrast to the term "private good" in which the product/service is consumed only by a particular member of society. A private good is an easy term to understand within the economics discipline, since private goods are produced and sold by businesses. But public goods are in the domain of government; and government is usually studied outside of economics, as for example in political science.

Yet some economists do emphasize the importance of the concept. Martin Wolf wrote: "Public goods are the building blocks of civilization. Economic stability is itself a public good. So are security, science, a clean environment, trust, honest administration, and free speech. The list could be far longer. This matters, because it is hard to secure adequate supply. The more global the public goods, the more difficult it is. Ironically, the better we have become at supplying private goods and so the richer we are, the more complex the public goods we need. Humanity's efforts to meet that challenge could prove to be the defining story of the century ... (now) a central element of debate is how to avoid extreme financial instability. Such instability is a public bad. Avoiding it is a public good" (Wolf, 2012).

Wolf defined the term of public-good: "In economics jargon, a public good is 'non-excludable' and 'non-rivalrous'. Non-excludable means that one cannot prevent non-payers from enjoying benefits. Non-rivalrous means that one per- 
son's enjoyment is not at another person's expense. National defense is a classic public good. If a country is made safe from attack everybody benefits, including residents who make no contribution. Again, enjoyment of the benefits does not reduce that of others. Similarly, if an economy is stable, everybody has the benefit and nobody can be deprived of it" (Wolf, 2012).

This is a positive view of a public-good, but not all economists have regarded the term as positive. Wolf wrote: "Public goods are an example of what some economists have called a 'market failure'. The point is generalized in the language of 'externalities'-consequences, either good or bad, not taken into account by decision-makers. In such cases, Adam Smith's invisible hand does not work as one might like" (Wolf, 2012).

In financial regulation, one public good is to prevent collapses. Wolf concluded: "Some economists have tended to assume that the market economy is inherently stable. If so, stability is supplied automatically. Unfortunately, this is not so. A free-market economy can expand credit without limit, at zero cost. Since money supply is simply the liability counterpart of private credit decisions, instability is baked in the economic cake. For this reason, economic stability is a public good we find quite hard to supply. The consequences of the repeated failure to do so can also be dire. Even the late Milton Friedman believed that government intervention, via the central bank, was needed to prevent long chains of banking collapses" (Wolf, 2012).

We now shift from economic theory to political science theory; and we will see that theoretical distinction in political science, Idealism or Realism, is a set of concepts similar to the economists' Public-Private Good. (In this shift, we can set economic theory solidly within its interface with political science-as political economic theory).

The dichotomy of Idealism-Realism has long existed in political science theory. For example, Bent Flyvbjerg emphasized the importance of the two concepts of Idealism or Realism in political thinking: “... a strong civil society is a crucial condition of strong democracy. Empowering civil society is a central concern for the project of democracy ... But what is 'civil society'? ... Most writers on civil society agree ... that civil society has an institutional core constituted by voluntary associations outside the sphere of the state. The fundamental act of citizenship in a pluralist democracy is in forming (voluntary) associations ... the task of maintaining and redefining the boundaries between civil society and state are the two interdependent and simultaneous processes: the expansion of social equality and liberty, and the restructuring and democratizing of state institutions" (Flyvbjerg, 1998). In economic terms, a "free market" is a voluntary association of buyers and sellers; and government regulation defines its boundaries.

The idea of a civil society allows the voluntary association of citizens in a state to act freely and independently of state institutions. Freedom of the citizen to voluntarily associate enables the democratic goals of pursuit of social equality 
and liberty and limitation of arbitrary and undemocratic exercise of the power of the state. This is the Ideal theory of the Exogenous school, as a free market of voluntary association does not require a boundary (e.g. government regulation). The Real theory of the Endogenous school argues an economic free market requires the voluntary association of citizens in a state but within regulatory bounds (the state task of maintaining boundaries).

The concept of a "civil society" introduces methodological complications in all social science research (e.g. in political science and in political economy). This idea of a "civil compromise" (civil cooperation or civil collaboration) raises the problem about 1) the existence of power and 2) the distribution of power within society.

The idea of a "civil compromise" can have a normative implication: what ought to be a "civil compromise"?

Expressed in political economic terms: How can government regulation of a financial market enable proper civil compromises by private agents in the market (e.g. buying and selling financial assets).

This is the methodological problem of normative judgments versus empirical judgments in social science research-Idealism or Realism. In economic research, Idealism should operative in the government regulation in a market; while Realism will operate in how financial agents behave in the market.

Within contemporary political science in the last half of the twentieth century, this problem between the ideal or real (normative or empirical) became again the central methodological issue of not only political science but all social science, including economics. What is real about the nature of society, and what is ideal?

The distinction between social reality and societal ideal has been and continues to be at the methodological center of economic theory and political science theory.

Within political science, Bent Flyvbjerg provided a nice analysis of the two conflicting methodological approaches (Flyvbjerg, 1998). Flyvbjerg focused upon the writings of two influential political scientists of the late twentieth century: Jurgen Habermas and Michael Foucault. Flyvbjerg saw their differences as that of methodology:

1) Habermas approached research in political systems as a study of idealism in political theory-normative theory;

2) Foucault approached research in political systems as a study of realism in political theory-empirical theory.

Jurgen Habermas described political activities by focusing upon and identifying the political ideals around which people gather, associate, and identify. Habermas called this "discourse-ethics" of the politics. By the term "discourse", Habermas indicated that social ideals are discussed openly in the politics as a 
justification of political action. By the term "ethics", Habermas was indicating that the ideal of the discourse provided an ethical agreement around which a group associates.

Still there is a reality about power in all political situations - the reality of how power is actually used, as opposed to how the power is justified. Michel Foucault emphasized that this "reality-of-power" is an essential feature of social science methodology. Foucault argued that in any political situation (even focused around a "discourse-ethics") there was also another view to power-which is a "realism" about politics, the "power analytics" of the situation.

Flyvbjerg argued that their two approaches were complimentary and captured a modern political science methodology dichotomy (Idealism or Realism): “The works of Habermas and Foucault highlight an essential tension in modernity. This is the tension between consensus and conflict .... Habermas is the philosopher of 'Moralitat' (morality) based on consensus. Foucault ... is the philosopher of 'wirkliche Historie' (real history) told in terms of conflict and power" (Flyvbjerg, 1998). The Exogenous school focused exclusively on "Moralitat" (Ideal); whereas the Endogenous school argued the "wirkliche Historie" (Reality) was need to ground empirical economic theory.

Habermas had followed in the philosophical tradition of Rousseau, in which societal cooperation as a kind of "social contract" should exist between a government and its people. Habermas saw the morality of modern democracy as a "discursive consensus" for a democratic process (which defines the rules of governance in a constitution and provides justification for the exercise of government power by elected officials). This is Habermas' point about political morality as based upon consensus.

But how such consensus actually operates is through conflict-struggle by parties for election, funding of elections by special interests, formulation of laws and enforcement to benefit special interests rather than the general civil public. This is Foucault's point that the actual operation of any real democracy in a society is through conflict and the gaining and exercise of power.

Flyvbjerg's position is that both the Habermas/Rousseau and the Foucault perspectives on consensus and conflict in society are essential to the methodology of the social sciences (including political economics). The consensus-aboutpower-in-a group is constructed around an "ideal" expressed in a discourseethics of the group (Idealism) - Exogenous School. The reality-of-how-power-isactually-exercised-in-a-group is expressed in the power-analytics of the group (Realism)-Endogenous School.

Discourse-Ethics is the justification of power; while Power-Analytics is the exercise of power. In political-economics, government regulation of a market should be depicted as operating in a context of both discourse-ethics (public good) and power-analytics (private good). Regulation should balance public and private good-in the idealism of ethics and in the realism of politics. 
Financial regulation in economic systems is complicated by the two kinds of goods, public and private and by the two aspects of ethics and power. Regulatory law is the expression of the discourse ethics in the public good of a financial institution. Regulatory practice is how law is actually administered within the context of political power. To optimize the private good in the exercise of regulatory practice, private financial institutions attempt to influence the political process for legislating and implementing regulation. Private firms can also exert their own private good to the extent they comply with the spirit of regulatory law (discourse ethics) in addition to the practice of regulatory law (power analytics). We can summarize these concepts in a taxonomy about ethics and power in government regulation of a market (Figure 8).

For example about bank regulation, Hyman Minsky had emphasized that regulation (as "discourse-ethics") in bank examination, had increased in importance as banks became larger: "With the attenuation of customer and collegiate surveillance as a result of the risk absorption by broadly defined central banking, bank examination becomes increasingly important as an instrument for constraining the exposure to risk of banks. Bank examination is largely perfunctory-the domain of accountants who look for proper procedures, documentation, and obvious fraud-rather than an inquiry into the economic viability and the exposures to risk of banking organizations" (Minsky, 2008).

Regulation of the banking industry should attend to the "economic viability and risk-taking" of the financial structure. Economic theory which is intended to underpin regulatory principles for financial systems should provide an empirical and normative grounding for financial regulation-both the "power analytics" and "discourse ethics" of economic systems. Issues which should be addressed include:

- The appropriateness of a financial transaction and the conditions under which it creates both private and public good (e.g. trading or gambling);

- The appropriateness of a financial institution, and the conditions under which it creates both private and public good (e.g. bank or shadow bank);

- The appropriateness of relationships between financial institutions, and the conditions under which they create both private and public good (e.g. internal shadow banking in integrated banks);

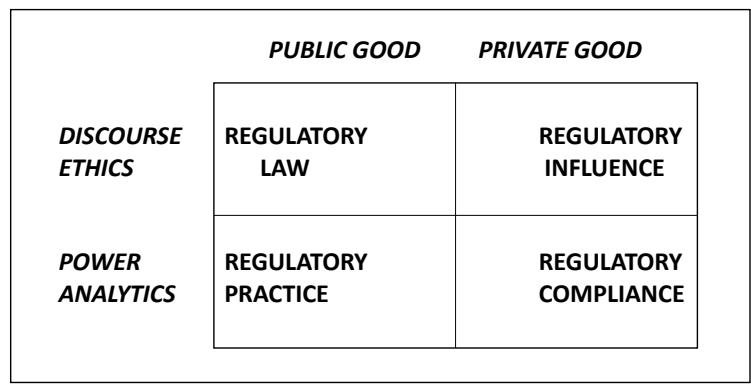

Figure 8. Ethics and power in regulatory behavior. 
- The appropriateness of financial market operations, and the conditions under which they facilitate both private and public good (e.g. unregulated derivatives markets);

- The appropriateness of the relationships between the financial institutions and a central bank, and the conditions under which both private and public financial good are protected (e.g. financial institution access to Federal central bank "discount window" loans).

\section{Game Theory-The Classical Form of the "Prisoner's Dilemma"}

How can the concept of government regulation as involving ethics and power (public good and private good) be depicted as a part of a model of financial markets (e.g. within a Keynes-Minsky disequilibrium model)? To do this, we next turn to an analytical approach called "game theory" to model the "idealism" and "realism" of agents' behaviors in a market. In Figure 9, we see the strategy matrix displaying the strategic choices (Strategy 1 and Strategy 2) of two players of the game (Player 1 and Player 2). The outcomes to the players under the four combinations of chosen strategies are shown in the game matrix. The rules of the game determining the outcomes of strategic choices are shown outside the game matrix, in a separate box.

The early famous game was called the "Prisoner's Dilemma". Two villains are apprehended in a place while attempting a robbery. The detective in charge has not enough evidence to convict them and offers each separately different possible outcomes, accordingly as to each one's strategy to trust or betray the other.

In prisoner dilemma form of the game, the detective defines the "rules of the game" being played by the two offenders. If the two trust each other and do not betray their plans to rob, then without evidence the detective can only charge them with trespassing; and each will go to jail for 6 months. However, if one

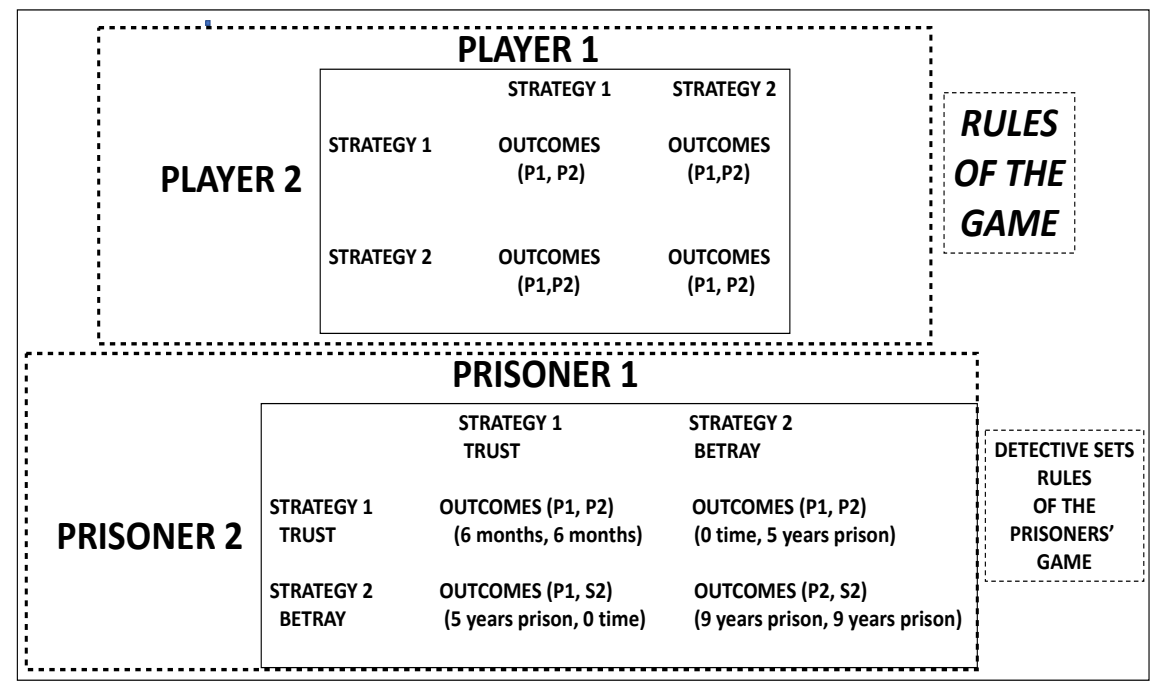

Figure 9. Game theory matrix and game theory matrix for prisoner's dillemma. 
does not trust the other, then the betrayer can go free, but the evidence the betrayer gives will enable the detective to change the betrayed villain with attempted robbery, receiving a jail sentence of five years. If both villains betray each other, the detective can have both convicted of attempted robbery with sentences each of nine years in prison. What do the two villains decide-to trust each other or betray each other?

The dilemma arises from the nature of the agents. The two prisoners are professional thieves (crooks, outlaws) with no lawful code of honor. Therefore, it is culturally difficult for them to trust each other in the situation of captivity. But "mutual trust" would have provided the best outcome for them. Yet to trust each other is most difficult. This is the dilemma.

\section{Historical Case and Analysis: 2007-2008 Financial Crisis in Game Theory Format}

Now in the historical example of the financial bubble of the mortgage derivative market, we can see that the best outcome for sellers and buyers would have been for them to trust each other. But the sellers (investment bank agents selling CDOs) broke the trust by issuing fraudulent investment assets. The CDOs were not really financial assets (with rents and future liquidity) because the interest payments (rents) had been sold off from long-term mortgage bonds. And then the bonds had no future liquidity. The CDOs were being sold, based upon "toxic assets". In this case in the betrayal of trust by the sellers, the real outcome for buyers was loss of investment. When the market collapsed, the real outcome for investment banks was bankruptcy.

We can analyze that historical economic event as modeled in a kind of "game." But it was a game in which the rules-of-game (ROG) permitted fraudulent behavior by sellers, as the government had declined to regulate the derivatives market - no rules of the game. In Figure 10, we now use the historical case of the 2007-2008 Great Recession as "empirical evidence" in formulating an economic-game-theory for a "Financial Market Game".

While traditional game theory formalized the strategy decisions, yet it had not always formalized the "rules-of-game". Here we are formalizing the "rules-ofthe-game" for economic games; and this becomes a game model of a Minsky financial bubble in 2007 (of the Mortgage Derivative Market). It depicts strategies of Trust or Betray between the two participants of Banks $(P 1)$ and Market Traders (P2). The Rules-of-the-Game (ROG) was a lack of regulation (No Regulation) by government regulators over the Derivatives Markets. This allowed the participants in the market, Banks (P1) or Market Traders (P2) to operate in the market with either Trust or Betrayal.

1) Outcomes (P1, P2) The Sellers of CDOs (Investment Bank Traders P1 and the Investment Banks P2, for which they worked) argued in the derivative market that the derivative contracts (CDOs) could be Trusted (as safe investments) because they were based upon mortgages. The Outcomes (P1, P2) were that the 


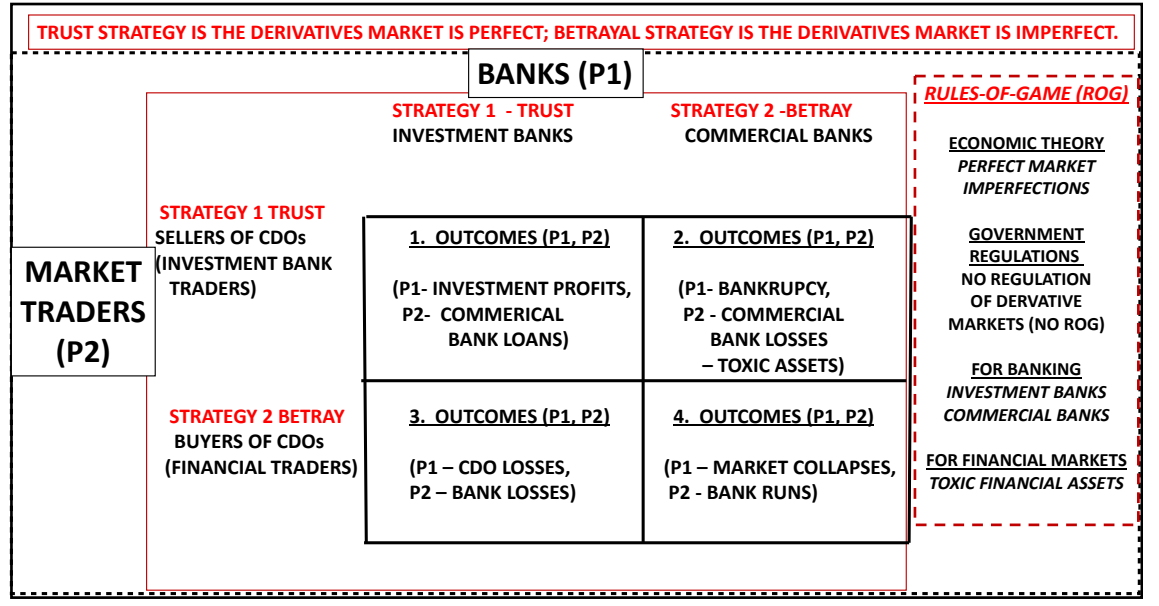

Figure 10. Imperfect financial-market dilemma game for the 2005-2008 securitization of the mortgage derivatives market (CDOs).

Investment Banks (P2) earned profits as commissions from selling the CDOs and the Commercial Banks (P1) made profits from the loans to the Investment Banks to purchase the mortgages.

2) Outcomes (P1, P2) The Sellers of CDOs (Investment Bank Traders P2 and the Investment Banks P1 for which they worked) argued in the derivative market that the derivative contracts (CDOs) could be Trusted (as safe investments) because they were based upon mortgages. But the Trust was false.

By stripping off the interest payments from the mortgage bonds to pay for the CDOs (derivatives), the underlying mortgage bonds became toxic (no longer had a future liquidity). Moreover, since the Investment Bank Traders did not pay for the mortgage bonds but borrowed from the Commercial Banks, the toxic mortgage bonds became worthless collateral; and the commercial bank loans to the investment banks were only in annual terms (needing to be renewed annually for the 30-year term of a home mortgage). Investment Banks made profits (2005-2007) only as long as the mortgage derivative market was trusted; and government regulators (e.g. U.S. Federal Reserve Bank and U.S. Treasury) trusted that all financial markets were perfect.

Thus, the Outcomes (P1, P2) were that for P2 the profits hoped for by Investment Bank Traders P2 stopped when the Commercial Banks P1 refused to renew the Investment Bank loans taken out to purchase mortgage bonds underlying their CDOs. Commercial Banks P1 feared that their Trust in the Traders P2 had been Betrayed, when they learned that large amounts of subprime mortgages had been purchased in the mortgage bonds. Commercial Banks P2 then refused to renew the short-term loans they had lent to Investment Banks P1.

At the time of trust in the mortgage-derivatives market, the leverage-loans (from commercial banks to investment banks) had been made possible by the "cheap money" policy of the Federal Reserve under Alan Greenspan. Morgenson and Rosner wrote: "All this is highly esoteric, of course. But the result was that Citigroup and other financial institutions were allowed to set up special invest- 
ment vehicles, or SIVs, that raised money by borrowing from investors for short periods and investing the proceeds in investments with longer terms (mortgages). The SIV would pocket the difference between the income generated by the mortgage and the amount paid out to investors who bought its obligations" (Morgenson and Rosner, 2011).

Yet this leveraging strategy was only a short-term financial tactic and never a long-term financial strategy. Morgenson and Rosner wrote: "This game worked while the mortgage mania was raging; but in 2007, when losses in subprime mortgages began to spook the markets. Investors fled SIVs in general and Citi's in particular ... Suddenly, Citi was left with mortgages ... (which) had to be either sold or brought back onto Citi's balance sheet at massive losses" (Morgenson and Rosner, 2011). The mortgage bonds stripped of interest payments (into derivative CDOs) made the mortgage bonds (held by Citi and other commercial banks) as "toxic".

3) Outcomes (P1, P2) The Outcome for Financial Traders P2 who purchased the derivative CDOs found their Trust betrayed by the Investment Banks P1 which sold them the CDOs, and P2 (traders) lost their money which they had invested in the CDOs. When the scandal broke on the poor quality of the CDOs, due to the inclusion of subprime mortgages in the mortgage bonds, the Outcome for Investment Banks who sold the derivative CDOs was enormous debt assumed in the loans from Commercial Banks to buy the mortgages. Their debt was so large as to threaten to bankrupt an Investment Bank P1.

The bonds, which the investment banks "securitized" into a CDO, were afterwards worthless as a financial asset. The banks had paid out money to buy the mortgages (which composed a bond) but then would have had to wait thirty-years to recover the bond principle through the mortgage payments (all that time receiving no interest from mortgage payments since the interest payments had been securitized, sold-off, as derivatives). Hence the bonds were not resalable. The investment banks only made money once as a commission in selling the derivatives of the $\mathrm{CDO}$, and afterwards the bonds they still held were illiquid, unsalable-for thirty years.

And the hedge-funds, which sold the CDOs, had betrayed by having CDOs fraudulently rated. They had assembled bad bonds (CDOs), which had deliberately mixed bad sub-prime mortgages (high-risk) with good prime mortgages (low-risk). They called the CDO a low-risk investment and bought low-risk ratings (AAA) from bond-rating agencies. But later the investors who had purchased the mortgage-securitized derivatives learned that the so-called "low-risk" derivatives were really "high-risk", full of sub-prime "very-high-risk" mortgages. All the CDOs then became financially "toxic"; and the derivatives market collapsed.

4) Outcomes (P1, P2) The Buyers of CDOs (P2) were betrayed by the Investment Banks and by Commercial Banks (P1), and when the financial markets crashed (derivatives, stock market, and money market), bank runs began. The runs first occurred in the Investment Banks and then in the Commercial Banks. 
The Outcome P2 for Trader investors in the CDOs was to lose all their investment; and the Outcome P1 for the Banks was bankruptcy or the threat of bankruptcy.

Betraya! Why had the hedge-funds done this? They did this for short-term commissions, in the sales of the CDO derivatives. They also hoped that the long-term "tomorrow" would never come. But "tomorrow" did arrive soon, and in 2008. Then hedge-funds could not refinance their CDO-borrowed-money (leverage) and collapsed. The banks loaning the hedge-funds the leverage-money also collapsed. First a Bear-Stern hedge fund collapsed, and then Bear Stern collapsed. Next a Lehman Brothers hedge fund collapsed, and then Lehman Brothers collapsed.

In 2008, the whole U.S. financial system was collapsing, and the Federal Government "bailed out" the Wall Street banks. Morgenson and Rosner wrote: "Of all the partners in the homeownership push, no industry contributed more to the corruption of the lending process than Wall Street. If mortgage originators like NovaStar or Countrywide were the equivalent of drug pushers hanging around a schoolyard and the ratings agencies were the narcotic cops looking the other way, brokerage firms providing capital to the anything-goes lenders were the overseers of the cartel" (Morgenson and Rosner, 2011).

The government market regulators, the U.S. Federal Reserve and the U.S. Treasury, stepped in to stop the economic crash by bailing out all the banks and the insurance company AIG (which had insured the CDOs). The U.S. Federal Government spent $3 / 4^{\text {th }}$ of a trillion dollars to save the banks. Based upon the exogenous economic theory of "perfect" financial markets, U.S. government policy turned out to be one of saving the banks after a financial bubble bursts (rather than regulating to prevent financial bubble).

When a bank makes a loan, the way to reduce risk is to own an asset more valuable than the loan, if the borrower fails on the loan. This is called collateral on the loan. But if a derivative does not have collateral, then insurance on the debt is essential. But how can one judge the proper insurance on a CDO, if it is composed of mortgages of different risk? Obviously, one cannot except by adding in a weighted manner, the risk on each mortgage. Bankers did not do this. Instead, fund managers made up a mathematical model to estimate risk, a "risk-management model". But any mathematical model is true only when based upon proper empirical data (garbage in, garbage out). Bond raters did not gather empirical data, relying instead upon what their customers told them. They were being paid by hedge fund managers to give high ratings to the securitized CDOs. George Soros commented: "The super-boom got out of hand when the new products (derivatives) became so complicated that authorities (bond raters) could no longer calculate the risks and started relying on the risk management methods of the banks themselves. Similarly, the rating agencies relied on the information provided by the originators of synthetic product. It was a shocking abdication of responsibility" (Soros, 2008).

In addition to the "toxic" CDOs, the so-called insurance for the "CDOs" 
which the firm AIG had issued were also worthless-because AIG could not pay off all the billions of dollars of CDO insurance contracts they had sold. AIG was about to be bankrupt until the US. Federal government "bailed out" AIG.

The banks had sold so many billions of dollars of derivatives that when the derivative market had suddenly become worthless, many of the major banks of the world had such large illiquid liabilities that they could not meet government-required minimum amounts of liquid capital - and so were in jeopardy of collapse. Then banks could not loan, even to each other; and all financial transactions between banks in the world temporarily ceased. The financial system of the world nearly stopped.

In sum, the game dilemma was "betrayal"-by worthless securitized assets, unpaid-for assets, fraudulent risk ratings, worthless insurance contracts, large illiquid liabilities. And there had been no proper government regulation to prevent a fraudulent financial market.

That regulation is necessary for financial markets to properly perform (to be perfect) has long been recognized in political practice but sometimes has been neglected in some schools of economic theory. The political institution of a central bank in a country has long been practiced to minimize political harm of bank failures, due to market imperfections.

Adding game-theory analysis into the models of financial markets can enable economic theory to formally express a positive institutional role for government regulation of private financial markets.

\section{Flow Models of Financial Institutions and Economic Games of Financial Agents}

Figure 11 shows how the models of institutional flows in a financial market connect to the game model of institutional agent strategies of the market, in the historical case of the financial bubble of 2007-2008.

What is particularly interesting about these two connected models is that one is a model of capital flow in financial institutions and the other about behavior of financial agents.

These institutions and agents are connected in this Endogenous model of the operations of a financial market. The Keynes-Minsky school had long argued that actions of institutions and behavior of agents could alter market activities, and this set of connected models (institutional flows and agent games) allows economic theory to depict real flows and real behavior in financial markets.

In a gaming model of financial agent behavior, by explicitly listing the "Rulesof-Game" (ROG), one can also see from the empirical evidence of the historical case the government regulators need to pay attention to proper rules for the following operations: 


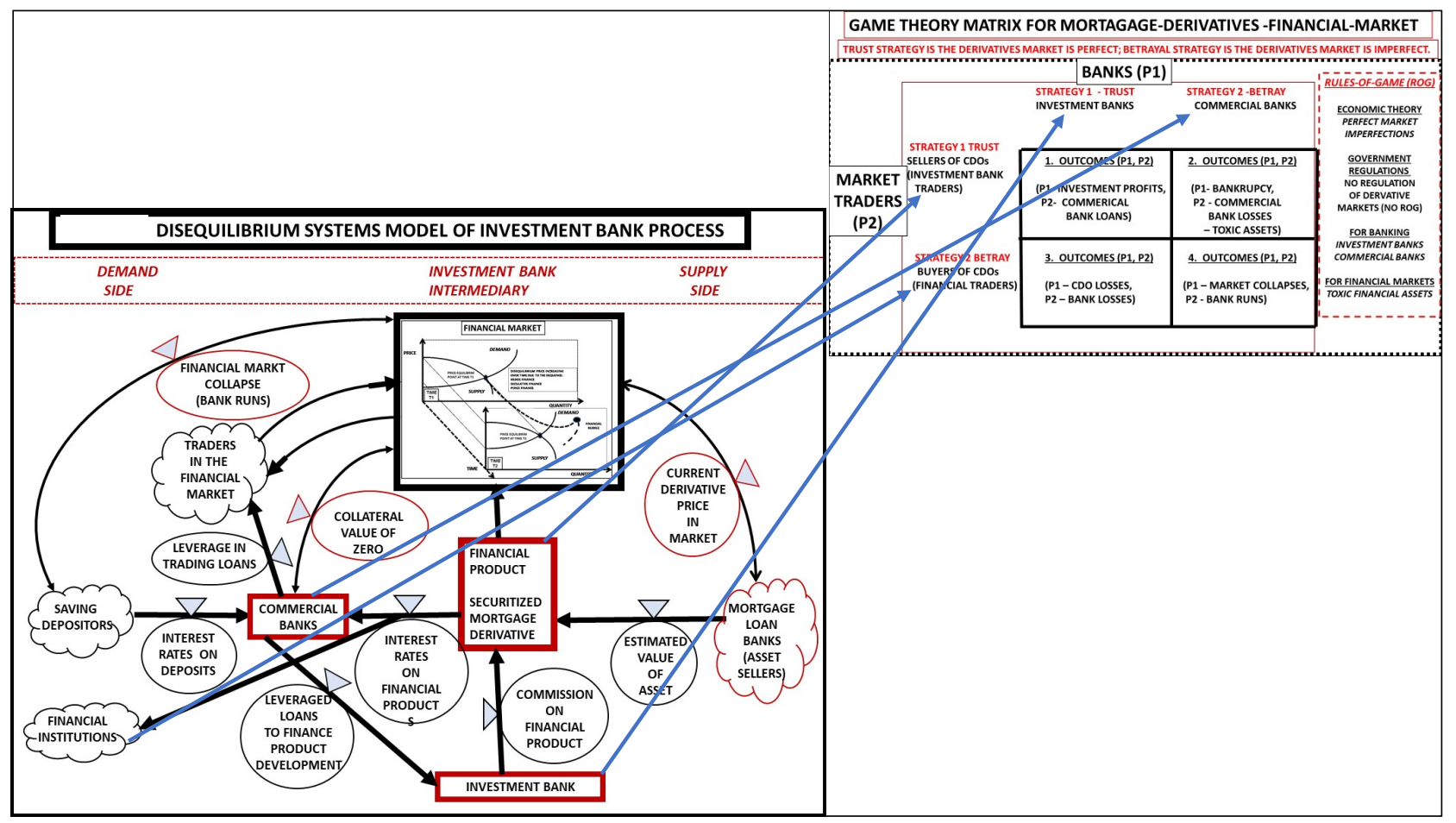

Figure 11. Connecting institutional-flows and agent-strategies in a financial market.

1) Economic theory used by Regulatory Agencies for Financial Markets should include consideration of the imperfections possible in a real market.

2) The principle function of government regulation is to implement proper R0G, so that financial markets operate for the public good as well as for private good of traders.

3) In regulating banks, government agencies should have proper rules for bank governance and for controlling margin loans.

4) In regulating stock markets, government agencies should have proper rules for controlling excessive leverage, irregularities in trading (such as "cornering") and controlling operations for stability in markets.

About the 2007-2008 financial crisis, Robert Kuttner summarized: “It wasn't until the 1980s and 1990s that Wall Street investment bankers and local mortgage originators came up with the scheme that led to the subprime collapse. This was all about inflating profits and passing along risks to someone else. It had nothing whatever to do with the Community Reinvestment Act. The investment bankers would bankroll local mortgage bankers to make subprime loans with low 'teaser' rates. By definition, a subprime loan is a loan to a customer who would not qualify for credit at the usual rates. After a few years, the interest rate on these loans would double or triple. Many borrowers defaulted. How could lenders make money on a product with a high risk of default? The investment bankers packaged the loans into bonds, known as collateralized debt obligations (CDOs). These were blessed with Triple-A ratings by private credit rating agencies and bought by unsuspecting investors all over the world. The investment 
bankers got the loan originators off the hook, and the bond buyers got the investment bankers off the hook. So local lenders could make unsound loans and investors could underwrite them, making a lot of money and passing along the risk to someone else. The whole process was corrupt, but in an era of deregulation, the regulators looked the other way" (Kuttner, 2020).

\section{Empirical Case: 2019 Federal Reserve's Vice Chairman for Supervision and Regulation}

If one requires even more empirical evidence that a game-theoretic model can be used to analyze financial agent behavior, consider the case in the U.S. of the weakening of regulatory laws passed after the financial debacle of 2007-2008.

Jeanna Smialek wrote: "In his first 21 months on the job, Randal K. Quarles, the Federal Reserve's vice chairman for supervision and regulation, met at least 22 times with partners at his former law firm, Davis Polk \& Wardwell, which represents many of the nation's largest banks. Those meetings, disclosed in public schedules and other releases, suggest a closeness between America's most important bank regulator and the industry he watches over. Mr. Quarles was a bank lawyer at Davis Polk in the 1980s and 1990s. At the Fed, he has conferred with former colleagues there, including Randall Guynn, a close friend. They at least occasionally came alongside officials of banks they represent, including Goldman Sachs, and trade groups including the Securities Industry and Financial Markets Association” (Smialek, 2019).

Jeanna Smialek wrote: "But the gatherings also suggest Mr. Quarles is meticulously completing the job President Trump nominated him to do. He is perhaps the most central player as regulators reassess bank rules put into place quickly, and often bluntly, in response to the 2008 financial crisis. Lawyers at Davis Polk, which has built a reputation as a top financial services practice, know how the rules are working and what the banks find problematic. That tension underlines a key challenge of financial regulation in 2019. Most current and former regulators agree that post-crisis rules could be improved. Banks' input can help policymakers determine which adjustments will enable more lending without encouraging excessive risk-taking. But catering to their interests too intently risks reigniting vulnerabilities in a financial system with a record of sinking the entire United States economy" (Smialek, 2019).

Jeanna Smialek wrote: "Critics warn that Mr. Quarles, 62 and a Utah native, is obliging Wall Street and ushering in weaker rules that will leave the banking sector more exposed. Supporters say he is exactly the right person to try to strike a balance, keeping safeguards in place while responding to legitimate concerns ... Mr. Quarles says he is aiming for efficiency. 'One of the objectives of the system should be an efficient system', he said in an interview. 'I think we've moved not too quickly, but quite quickly, in adjusting-again, with an eye toward efficiency-some aspects of post-crisis regulation"' (Smialek, 2019). It is interesting that Mr. Quarles chose "efficiency" as a ROG criteria and did not 
mention "instability".

Jeanna Smialek wrote: "The Fed is giving big banks more insight into how it conducts annual stress tests, checkups that ensure firms have enough capital to weather a downturn. It largely eliminated an option that allowed bank supervisors to flag weaknesses in capital planning processes during stress testing. Mr. Quarles has gotten plenty of feedback throughout the process, averaging about 100 formal meetings a month with banks, lawmakers, government colleagues and others. He has talked with Davis Polk more often than other law firms, but executives from Goldman Sachs and JPMorgan have also met with him about 20 times each. 'I have a pretty open door,' he said. 'I think that's part of the responsibility of a Fed governor. The Fed as an institution has to be open to receiving input"' (Smialek, 2019). In Figure 12, the frequency of meetings is listed of a government regulator with financial institutions and agents and with polititians-all interested in the game of regulation.

In economic history, the ROG (Rules of the Game) for a financial market are sometimes negotiated for compliance (Moralitat) between government negotiators and behavior of financial agents (wirkliche Historie).

\section{Discussion}

The "Great Recession" Financial Crisis of 2007-2008 has been studied by many economists. For example, Neil Fligstein and Adam Goldstein wrote: "The proximate cause of the 'Great Recession' was the unraveling of the mortgage securitization industry beginning in 2007 . What had been a relatively small niche market at the beginning of the 1990s was, from 1993 to 2007, transformed into the core activity of the rapidly expanding financial sector. At the peak of the mortgage business, in 2003, the financial sector, comprising about 10 percent of the labor force, was generating 40 percent of the profits in the American economy. These profits were mostly being made from businesses engaged in selling mortgages and creating various forms of mortgage-backed securities (securitization) ... In 2003, the mortgage business represented a $\$ 4$ trillion industry. Beginning in late 2006 and early 2007, the housing and mortgage-backed securities markets began to collapse, taking the larger financial sector down with them by the end of 2008" (Fligstein and Goldstein, 2011).

The securitization derivative products (CDOs) had ballooned to a market of $\$ 4$ trillion. Neil Fligstein and Adam Goldstein wrote: "But perhaps most important of all was the fact that regulators such as Alan Greenspan failed to see how the industrial-scale infusion of credit brought on by securitization-linked real estate markets together in new ways ... It was no accident that the locus of this historic debacle was housing finance. Securitization was first developed in this area ..." (Fligstein and Goldstein, 2011).

The "securitization innovation" resulted in creating financial products for a new financial market of "securitized mortgages". The basic economic problem with this market was that these securitized financial products (CDOs) were not 


\section{Some of Quarles's Frequent Meetings}

The Fed's supervisory vice chair talks with lawyers at Davis Polk, his former employer, often. Here area a few groups he met with regularly between October 2017 and June 2019

$\begin{array}{ll}\text { Republican Senators } & 29 \\ \text { Goldman Sachs } & 23 \\ \text { Davis Polk } & 22 \\ \text { Republican Representatives } & 21 \\ \text { JPMorgan } & 20 \\ \text { Morgan Stanley } & 17 \\ \text { Democratic Senators } & 17 \\ \text { Citi } & 12 \\ \text { Democratic Representatives } & 6 \\ \text { Sullivan \& Cromwell } & 4\end{array}$

Note: In two cases, Davis Polk representatives were not listed but their attendance was recorded elsewhere. Chart ignores central bank, administration and regulatory officials. Sullivan \& Cromwell included for comparison. Large-group meetings with lawmakers not included. By The NewYork Times. Source: Federal Reserve Freedom of Information Act disclosure

Figure 12. Frequencies of quale's meetings in 2019 as federal reserve's vice chairman for supervision.

really financial assets. As we earlier noted, a financial asset has two properties: current rent and future liquidity. The CDOs stripped the interest payments (rents) from the mortgage bonds underlying a CDO; and the mortgage bonds were no longer a real financial asset. Moreover, the mortgage bonds were no longer liquid because they could not be resold by without their interest payments.

The unregulated derivatives market allowed many kinds of economic "betrayal". Alirzayev E.V. and Suleymanov E.B. wrote: "Beginning with low interest rates set by FED, US government political pressures to enable more Americans to buy homes, unrestrained financial system despite of regulations and fines, human greed were the main reasons for Great Recession ... Financial institutions made, bought, and sold mortgage securities they never examined, did not care to examine, or knew to be defective; firms depended on tens of billions of dollars of borrowing that had to be renewed each and every night, secured by subprime mortgage securities; and major firms and investors blindly relied on credit rating agencies as their arbiters of risk" (Alirzayev and Suleymanov, 2013).

The investment banks bought mortgages but did not pay for them; instead, they borrowed yearly loans to refinance the purchase, year by year. We recall that the securitization fund in Bear Sterns had bought 6 billion dollars of mortgages, which they securitized. But the $\$ 6$ billion was borrowed from a commercial bank for a term of only one year. After two years, when the commercial bank failed to renew the $\$ 6$ billion loan, Bear Sterns was on the hook for the $\$ 6$ billion, while it then had only $\$ 2$ billion in assets. Bear Sterns was the first bankruptcy of the "Great Recession". The U.S. government did not bail out Bear Sterns nor the following Lehman Brothers bankruptcy nor the Merrill Lynch sale.

But the Federal government bailed out the commercial banks and the insurance company AIG (which together had made the billions of dollars in shortterm loans to the securitization hedge funds of the investment banks and had 
also insured the CDOs). About the Federal bailout, Terrence Casey wrote: "In October 2008, Congress approved the Emergency Economic Stabilization Act, 15 establishing the Troubled Asset Relief Program (TARP), which authorized the Treasury to spend up to 700 billion dollars to promote stability in the markets through the purchase of 'toxic assets'. As originally presented by Hank Paulson, the Treasury would buy assets from insolvent backs and then sell them at some form of auction. This idea quickly proved a non-starter. For one, the complexity and opacity of these instruments, combined with the fact that the market for their underlying value was plummeting, made it exceptionally difficult for anyone to determine a meaningful underlying value ... Faced with these complexities, the Treasury shifted gears from asset purchases to capital injections, purchasing $\$ 205$ billion in preferred stock from 707 financial institutions. Three institutions received the lion's share of the funding. Citigroup and Bank of America (who also swallowed up Merrill Lynch) each received $\$ 40$ billion in capital purchases of preferred and common stock, with Citigroup receiving and additional $\$ 5$ billion in guarantees against losses on $\$ 301$ billion of covered assets. Insurance giant AIG got $\$ 70$ billion, $\$ 40$ billion in stock purchases and a $\$ 30$ billion line of credit" (Casey, 2010).

The "securitized assets" were "toxic" (unsellable) because they were no longer technically "financial assets" as the rents (interest payments) had been stripped (sold off) from the mortgage bonds. While the mortgage bonds might still collect mortgage payments, the mortgage bonds received only the principle part of the payment. In selling a securitized mortgage bond, the buyer would be receiving only the principle part of the payments, without any interest being received for the life of the mortgage. Who would buy a securitized mortgage bond which paid no interest for the 30 years of the mortgage? Answer: no one. Toxic asset.

Why was this mortgage securitization product allowed by Federal regulators? To answer this kind of question, Charles Calomiris and Stephen Haber wrote about the financial system as not just an economic thing but as political-economics: "We recognize that politics is everywhere, but somehow we believe that banking crises are apolitical, the result of unforeseen and extraordinary circumstances, like earthquakes and hailstorms. We believe this because it is the version of events told time and again by central bankers and treasury officials, which is then repeated by business journalists and television talking heads. In that story, well-intentioned and highly skilled people do the best they can to create effective financial institutions, allocate credit efficiently, and manage problems as they arise-but they are not omnipotent. Unable to foresee every possible contingency, they are sometimes subjected to strings of bad luck. 'Economic shocks,' which presumably could not possibly have been anticipated, destabilize an otherwise smoothly running system. Banking crises, according to this version of events, are much like Tolstoy's unhappy families: they are all unhappy in their own ways. We take exception with that view and suggest instead that the politics that we see operating everywhere else around us also determines whether socie- 
ties suffer repeated banking crises (as in Argentina and the United States), or never suffer banking crises (as in Canada). By politics, we do not mean temporary, idiosyncratic alliances among individuals of the type that get the dumbest guy in the company promoted to vice president for corporate strategy. We mean, instead, the way that the fundamental political institutions of a society structure the incentives of politicians, bankers, bank shareholders, depositors, debtors, and taxpayers to form coalitions in order to shape laws, policies, and regulations in their favor-often at the expense of everyone else. In this view, a country does not 'choose' its banking system: rather it gets a banking system that is consistent with the institutions that govern its distribution of political power" (Calomiris and Haber, 2014). This is the "agent-and-institutional" method we have used in this research.

Bank crises are usually failures of solvency or liquidity due to the failure of financial markets in which the banks have funded leveraged loans. The point of government regulation is to ensure banks limit financial risk by not funding too much leverage for a market and/or not funding loans to fraudulent financial markets. Charles Calomiris and Stephen Haber wrote: "We regard banking crises as either systemic insolvency crises or systemic illiquidity crises. Some crises, like the subprime lending crisis in the United States, and the other U.S. crises in $1837,1839,1857,1861$, the 1920s, 1930-1933, and the 1980s, have involved extensive bank insolvency, not just moments of illiquidity when banks experience severe withdrawal pressures ... Bank insolvency crises are usefully defined as events during which the negative net worth of banks, or the costs of government interventions to prevent those insolvencies, exceed some critical percentage of GDP" (Calomiris and Haber, 2014).

Game theory has been extensively applied in business decision making and in war gaming but not in financial regulatory decisions. For example, Pieter Bots and Leon Hermans wrote: "If public policy making is viewed as a negotiation process, the complexity of this process will increase roughly in proportion with the number of stakeholders involved, the variety of their interests, the variety of available options, and the time frame within which decisions are to be made. The complexity of the negotiation process also depends on the extent to which information on each of these factors is available to the stakeholders ... The general purpose of stakeholder analysis is to gain such insight in a policy problem that stakeholder strategies can be anticipated and evaluated in terms of the negotiation process and its outcome" (Bots and Hermans, 2003).

\section{Conclusion}

The novel contribution of this research is to add a "game theory" approach to express "financial-market-regulations" as "rules-of-the-game"-in order to bound "proper trading" in the financial market. "Proper trading" in a financial market contributes not only to the private-good of traders but also to the public-good of a financial market-in providing needed capital for legitimate eco- 
nomic operations. A game-theoretic approach enables the modeling of an actual event of a market instability-to understand when financial markets fail due to excessive speculation or to fraudulent financial products-uncontrolled by effective regulation.

As we have reviewed, a "consensus about power" in a group is constructed around an ideal expressed in the discourse-ethics of the group (idealism). In contrast, the "reality of how power is really exercised" in a group is expressed in the power-analytics of the group (realism). In economic theory, public good is a discourse-ethics theory of an economy (idealism) and private good is a power-analytics theory of an economy (realism). Economic theory of financial markets should be capable of analytically modelling both the Idealism of the Public Good and the Realism of Private Good in an economic market.

To base economic theory and models upon empirical reality (ground theory), one should use historical and contemporary case studies of economic crises. Contemporary cases are a blend of the case approach and historical methodology. In historical methodology, sources and direct quotes provide evidence of historical information and interpretation. Contemporary case studies derive historical information from investigative reporters on economic and financial events and on the interpretation of these events by contemporary economists and economic commentators. The direct quotes in case studies point to sources of historical evidence on the crisis events. Case studies in economics can be used to provide a basic empirical technique in institutional and micro-economic analyses of the validity of economic theory and models. And economic historians have produced a rich and extensive literature about the "real" events in economic history-an important source for validating economic theory, ideal or real.

In scientific method, to be valid as a general theory, any social science theory must be examined either as an "empirical law" or as a "normative law". Empirical laws are "value-neutral", while normative laws are "value-loaded". In the social sciences, empirical laws explain what "happened"; while normative laws explain what "should-have-happened". Empirical laws occur in reality; and while normative laws should occur in reality (but empirically, they may or may not). Facts occur in reality, and empirical models depict that reality (wirkliche Historie). But normative social science theory may or may not actually occur (Moralitat).

The commodity market theory of "price-equilibrium" is a normative law but not always an empirical law. The Exogenous School's price-equilibrium model of a "perfect market" is an ideal (a norm) which economic markets should attain. But it is not generally true (always true) as an empirical law. This is because any particular commodity market may or may not be operating perfectly in a price-equilibrium point (at which price is set by market demand exactly matching supply). Empirically, a commodity market can be in price-equilibrium, but only when the actual conditions of the market enable such equilibrium. Any commodity market depends upon the actual conditions of the market, its market 
context. Even a commodity market is not empirically in price-equilibrium, except in a proper context, such as: the supply capacity being insufficient to meet demand, no monopolies over supply, safe and legal products in supply, etc.

Exogenous economists have termed the lack of proper conditions as "market imperfections". But empirically, there are no "imperfections" in a market! There is only a "reality" in any market. Methodologically, "imperfections" occur not in "reality" but only in a "theory". An empirical theory is "imperfect" when it is not "valid" in reality.

A normative theory is "perfect" only when political morality is based upon a democratic consensus over historical time. The occurrence of a real condition of price-equilibrium in a commodity market (when supply equals demand) is a desirable condition. Price-equilibrium is a desirable characteristic of an economic system-a normative law. It can be applied to commodity markets for guiding policy (with proper safety regulation); but it should never be applied to financial markets without realistic and appropriate government regulation. Historically, regulatory policy based upon invalid (not Real) economic theory has facilitated financial instabilities.

\section{Conflicts of Interest}

The author declares no conflicts of interest regarding the publication of this paper.

\section{References}

Alirzayev, E. V., \& Suleymanov, E. B. (2013) Government Role during the Global Financial Crisis. World Research Journal of Economics, 2, 13-21. https://doi.org/10.2139/ssrn.2355981

Bernake, B. S. (2007). Global Imbalances: Recent Developments and Prospects. Budesbank Lecture, Berlin, September 11. http://citeseerx.ist.psu.edu/viewdoc/download?doi=10.1.1.471.4631\&rep=rep1\&type=p df

Betz, F. (2014). Disequilibrium Pricing Theory-Bubbles and Recessions. Theoretical Economics Letters, 4, 60-67. https://doi.org/10.4236/tel.2014.41009

Betz, F. (2015). Price-Disequilibrium Model of the International Financial Grid: Innovation, Crisis, and Off-Shore Banking. Business and Management Research, 4, No. 3; https://doi.org/10.5430/bmr.v4n3p43

Betz, F., \& Khalil, T. (2011). Technology and Financial Innovation. International Journal of Innovation and Technology Management, 8, 1-25. https://doi.org/10.1142/S0219877011002155

Bots, P. W. G., \& Hermans, L. M. (2003). Developing "Playable Metagames” for Participatory Stakeholder Analysis. In K. Arai (Ed.), Proceedings of the 34th Conference of the International Simulation and Gaming Association (ISAGA). Chiba: Japan Association of Simulation and Gaming.

Calomiris, C. W., \& Haber, S. H. (2014). Fragile by Design: The Political Origins of Banking Crises \& Scarce Credit. Princeton, NJ: Princeton University Press.

Casey, T. (2010). The End of the Affair? Free Market Capitalism in the US and UK after the Financial Crisis. Terre Haute, IN: Department of Humanities and Social Sciences, 
Rose-Hulman Institute of Technology.

Fisher, I. (1933). The Debt-Deflation Theory of the Great Depression. Econometrica, 1, 337-357. https://doi.org/10.2307/1907327

Fligstein, N., \& Goldstein, A. (2011). The Roots of the Great Recession. In D. B. Grusky, B. Western, \& C. Wimer (Eds.), The Great Recession (pp. 21-56). New York: Russell Sage Foundation. http://www.jstor.org/stable/10.7758/9781610447508

Flyvbjerg, B. (1998). Habermas and Foucault: Thinkers for Civil Society? British Journal of Sociology, 49, 210-233. https://doi.org/10.2307/591310

Goodman, P. S. (2008). Taking Hard New Look at a Greenspan Legacy. New York Times, October 8.

Keynes, J. M. (1936). The General Theory of Employment, Interest, and Money. San Diego', CA: Harcourt Brace.

Kindelberger, C. P., \& Aliber, R. Z. (2011). Manias, Panics, and Crashes. A History of Financial Crises (6th ed.). London: Palgrave Macmillan.

Kuttner, R. (2020). I Wrote the Law Bloomberg Blames for the Financial Crisis. He's Wrong. Washington Post, February 15.

https://www.washingtonpost.com/outlook/2020/02/15/i-wrote-law-bloomberg-blamesfinancial-crisis-hes-wrong/

McCulley, P. (2009). Saving Capitalistic Banking From Itself. PIMCO, February.

Mcgee, S. (2010). Chasing Goldman Sachs: How the Masters of the Universe Melted Wall Street Down...And Why They'll Take Us to the Brink Again. St. Louis, MO: Crown Publishing Group.

Minsky, H. (1975). John Maynard Keynes. New York: Columbia University Press. (Reprinted in 2008 by McGraw Hill) https://doi.org/10.1007/978-1-349-02679-1

Minsky, H. (1993). Comment on Ben Bernanke, "Credit in the Macro-Economy". Hyman P. Minsky Archive, Paper 361. http://digitalcommons.bard.edu/hm_archive/361

Minsky, H. (2008). Stabilizing an Unstable Economy. Boston, MA: McGraw Hill.

Minsky, H. P. (1969). Private Sector Asset Management and the Effectiveness of Monetary Policy: Theory and Practice. The Journal of Finance, 24, 223-238. https://doi.org/10.1111/j.1540-6261.1969.tb01676.x

Minsky, H. P. (1982). Can “It" Happen Again? Essays on Instability and Finance. Armonk, NY: M. E. Sharpe Inc. https://doi.org/10.1080/05775132.1982.11470774

Morgenson, G., \& Rosner, J. (2011). Reckless Endangerment: How Outsized Ambition, Greed, and Corruption Led to Economic Armageddon. New York: Henry Holt and Company.

New York Times (2008). Credit Crisis. The New York Times, December 8.

Nocera, J., \& Carvell, T. (2000). 50 Lessons. Fortune, October 30, 136-137.

Smialek, J. (2019). Meet the Man Loosening Bank Regulation, One Detail at a Time. New York Times.

https://www.nytimes.com/2019/11/29/business/economy/bank-regulations-fed.html?se $\underline{\operatorname{archResultPosition}=2}$

Soros, G. (2008). The Worst Market Crisis in 60 Years. Financial Times, January 22.

Whalen, C. J. (2012). Post-Keynesian Institutionalism after the Great Recession. Working Paper No. 724, Levy Economics Institute of Bard College.

https://doi.org/10.2139/ssrn.2062469

Wolf, M. (2012). The World's Hunger for Public Goods. Financial Times, January 24. 